\title{
CORPORATE POLITICAL AFFAIRS PROGRAMS
}

THE recent flowering of the business-in-politics movement ${ }^{1}$ adds new dimensions to an old problem: what limitations should the law impose on corporate political activity? Corporations have always been involved in politics. In the nineteenth century this involvement took the form of campaign contributions, unregulated lobbying, and often bribery. ${ }^{2}$ The more detrimental effects of these activities have been largely curbed, bribery and contributions by Corrupt Practices Acts and lobbying by strict registration requirements. ${ }^{3}$ But a new and more significant form of corporate political activity has been developing in recent years. In part, this development has been a reaction to the growth of Big Government, a negative attempt to avoid the irritating impact of government regulation ${ }^{4}$ and a positive effort to share in governmentally dispensed benefits." It has been stimulated by the emergence of a new philosophy of corporate behavior, which teaches that corporations must discharge social as well as commercial responsibilities. ${ }^{6}$

The problem is presented in its most acute form when political programs are adopted by large publicly held corporations controlled by their own man-

1. See Bart, Big Corporations Mount Soapboxes, the N.Y. Times, May, 29, 1960, § 3 , p. 1, col. 2; Opinion Research Corp., Realistic Policy for Business in Politics, 45-49 (October 1959) ; Hazard, It Takes Money To Get Elected, The Atlantic, Feb. 1960, p. 92; Taft, Should Business Go In For Politics, N.Y. Times Magazine, Aug. 30, 1959, p. 10.

2. See Sikes, Corrupt Practices Legislation 188-92 (1928).

3. See, e.g., Federal Corrupt Practices Act, $\S 301,43$ Stat. 1070 (1925), 2 U.S.C. $\S \S$ 241-56 (1958); 18 U.S.C. $\$ 610$ (1958); Federal Regulation of Lobbying Act, 60 Stat. 839 (1946), 2 U.S.C. $\$$ 261-70 (1958); The Assocration of the Bar of the City of New York, Conflicts of Interest and Federal Service 144 (1960) [hereinafter cited as CONFLiCt OF INTEREST].

4. See, e.g., A Political Program For Gulf Oil Corporation, June, 1959, p. 2 [hereinafter cited as Gulf Programe. Hazard, supra note 1, at 92-93. See also the N.Y. Times, Jan. 21, 1961, p. 32, col. 5 (utilities seek to terminate federal power project).

5. See, e.g., Advertisement, Ass'n of Amer. R.R., Harv. Bus. Rev., Mar.-April 1960, p. 43 (plea for greater public solicitude).

6. One of the earliest expressions of this philosophy is Dodd, For Whom Are Corporate Managers Trustees, 45 Harv. L. Rev. 1145 (1932). Modern echoes are legion. See, ig., Advertisement, N.Y. Times Book Review Section, Jan. 8, 1961, p. 30 ("PitneyBowles is more than an economic unit; it is a socially conscious institution."); Have Corporations A Higher Duty Than Profits?, Fortune, Aug. 1960, p. 108; Hazard, supra note 1, at 93; Livingstone, The American Shareholder 219-20 (1958); Berle, Power Without Property $\&$ (1959). The "corporate citizenship" theme, has been taken up by courts. See, e.g., Union Pac. R.R. Co. v. Trustees, Inc., 8 Utah 2d 103, 106, 329 P.2d 398 (1958) ; A. P. Smith Mfg. Co. v. Barlow, 13 N.J. 145, 98 A.2d 581 (1953). It has led to an impressive increase in the flow of corporate funds into charitable activities, Union Pac. R.R. v. Trustees, stpra, as well as a renewed sense of self-importance for businessmen. See, e.g., Advertisement by International Latex Corp., The N.Y. Times, April 26, 1960, p. 14, col. 1 ("You and every man in business are trustees of this nation and the world").

For dissenting views, see Kelso, Corporate Benevolence or Welfare Distribution?, 15 Bus. LAw. 259, 266 (1960); Rostow, stipra note 2, at 46, 59-71. 
agement-what Dean Rostow has called "endocratic corporations." Endocratic corporations can place enormous power behind political programs, bringing to bear all the organized resources of money and talent which underlie their commercial success. ${ }^{8}$ Their programs may be particularly effective because of the skill and experience acquired by these corporations in the use of new techniques of mass persuasion. ${ }^{9}$

These modern attempts at corporate political action present more subtle problems than the traditional forms of corporate politicking. While these problems are by no means peculiar to the endocratic corporation, but indeed arise in some form whenever great wealth is controlled by few persons, it is impossible to consider the distinct problems raised by each institution in a single Comment. This Comment will describe the new forms of corporate political activity, analyze their impact upon shareholders, employees, and the public, and explore alternative means of regulation.

\section{Varieties of Corporate Political Activity}

Corporate political affairs programs take three forms: (1) attempts to create public support for selected legislative goals, specific legislation, or particular candidates; (2) maintenance of training programs designed to develop the political skills and interests of employees; and (3) provisions for employee participation in political activity during business hours. To constitute a "program" the activity must be in furtherance of a continuing policy, consciously adopted by corporate officials. So defined, isolated instances of one or another of the above activities are excluded from consideration.

To provide a factual basis for this Comment a Political Activity Questionnaire was sent to a group of the largest corporations in the United States chosen on the basis of size. Of one hundred and fifty corporations solicited, thirty two replied. Unfortunately, the small number of useful replies makes meaningful generalization impossible. When appropriate, however, results of the poll have been utilized to indicate the variety of arrangements and subject matter involved in these programs. ${ }^{10}$

\section{Generating Public Support}

The responses illustrate the varied means utilized to create widespread support among employees, shareholders, and the public for specific legislation or

7. Dean Rostow has attributed the term to Herman W. Liebert. See Rostow, To Whom and For What Ends Is Corporate Management Responsible, in MAson, Tre CoRPORATION IN MODERN SOCIETY 46, 302-03 nn.1 \& 2 (1960).

8. See Kelso, supra note 6 , at 262; Berle, The Twentieth Century Capitausst REvolution 162-63 (1954).

9. See Ross, The Image Merchants 27 (1959); cf. Pimlott, Public Relations AND AMrRICAN DEArocracy 71-77 (1951) (discussing dangers of federal government's use of public relations techniques to mold opinion).

10. Of those responding, ten did not fill out the form but supplied some information. Questionnaire responses are cited QUEsTIONNATRE. 
particular candidates and for selected axioms of political and economic theory. Political propaganda has been disseminated though shareholder reports, ${ }^{11}$ employee newsletters, ${ }^{12}$ intracompany memoranda, ${ }^{13}$ advertisements in mass media publications, ${ }^{14}$ posters on company premises, ${ }^{15}$ notices in employee pay envelopes, ${ }^{10}$ pamphlets distributed to employees, ${ }^{17}$ and movies shown to them. ${ }^{18}$ Other sources indicate that corporations frequently contribute to civic, educational, and business organizations which support legislation or a political view-point favored by corporate officials. ${ }^{19}$ Barred from making direct

The Yale Law Journal wishes to thank those corporate officials who were kind enough to fill out the questionnaires and to supply documents and other supplementary materials which have proven useful in the preparation of this Comment.

11. See, e.g., Mutual of New York, 114th Annual Report 6-8 (1956) ; Jones \& Laughlin Steel Corp., 1956 Annual Report 2; General Electric, 1959 Annual Report 25; Virginia Electric and Power Co., Quarterly Report, June, 1959. Of thirteen companies answering this section of the questionnaire, ten utilized shareholder reports to communicate political views to shareholders.

12. All thirteen companies answering this section of the questionnaire utilized company newsletters for political comment.

Some of these comments were keyed to the recent national election. See Bart, supra note 1 .

13. This medium was utilized by eleven companies who sought to create a favorable political climate, and by ten companies supporting specific legislation. Schering Corp. (not one of the companies polled), urged its employees to contact their Congressmen to urge passage without amendment of the Eisenhower aid to the aged bill and defeat of the Forrant Bill. The company identified the bills by number only and urged co-operating employees to send copies of their letters either to the company or to a trade association of which it was a member. Kempton, Don't Write-Telegraph, The N.Y. Post, Aug. 25, 1960, p. 37, col. 1. See Baumer \& Herzberg, Politics Is Your Busrness 41 (1960) (bring "facts" to attention of employees so they may judge for themselves); id. at 130-31 (news bulletins for "guidance") [hereinafter cited as BAUArer \& HerzBerG]; Companies" Role in the Election, Business Week, Nov. 26, 1960, p. 36 (company v.p. urges employees to vote for director running against Senator Douglas).

14. Mass media were utilized by five companies to create a "favorable business climate" and by three companies to secure passage of selected legislation. QUESTIONNAIRE. A "favorable business climate" is an attitude on the part of legislators and elected executives sympathetic to the interests of the corporation as defined by its management. See Companies' Role in the Election, supra note 13.

15. Only one company used posters to create a favorable climate or support for legislation. QuestionNarre.

16. This medium has been used only in support of better business climate programs. QuestronNarre. State statutes may prohibit use of pay envelope notices to accomplish more specific political ends. See, e.g., MIcr. Srar. ANn. \$ 6.1912 (1956).

17. Five companies distributed pamphlets to employees in support of "climate" creation; six to help generate support for legislation. QuEsTroNNATRE.

18. See authorities cited note 1 supra.

19. See, e.g., State v. Cleveland-Cliffs Iron Co., 169 Ohio St. 42, 157 N.E.2d 331 (1959) ; Eastern R.R. President's Conference v. Noerr Motor Freight, Inc., 29 U.S.L. WeEk 4191 (Sup. Ct., Feb. 20, 1961), Note, 70 YaLE L.J. 135 (1960). For an analysis of the associations through which corporations seek to affect legislative decision, see Comment, 69 Y ALE L.J. 1017, 1037-48 (1960). Until recently there may have been a tax advantage in using these groups. See generally Comment, 69 YAIE L.J. 1017, 1032-50 (1960). 
contributions to candidate and party campaign funds by corrupt practices legislation, corporations have found several ways to transfer funds secretly. Employees, attorneys, or public relations counsel collect unearned income with the understanding that the money, minus adjustments for income taxes payable, will be passed on to parties and candidates. ${ }^{20}$ Employee expense accounts are tapped for tickets to party fund-raising affairs, ${ }^{21}$ advertising departments purchase space in party journals, ${ }^{22}$ and earmarked contributions are made to trade and civic organizations which pass them on to designated politicians. ${ }^{23}$ The corporation may spend the money itself, using its institutional advertising to propagate ideas clearly associated in the public mind with particular candidates or a political party. ${ }^{24}$

The locus of responsibility for selecting and implementing political objectives varies from corporation to corporation. In some corporations one or a few key officials make this decision, while in others political decision making has been decentralized to lower echelon executives. ${ }^{25}$ In a few instances special departments have been created. ${ }^{26}$ Some companies have delegated a substantial part of their discretion to business groups and trade associations to which they contribute. ${ }^{27}$

Some corporate political campaigns are directed at national measures closely related to the company's business operations. For example, oil companies have mobilized support for retention of the petroleum depletion allowance, ${ }^{28}$ and natural gas pipeline companies have campaigned to revise rate-making standards $;^{29}$ electric light and power companies have vigorously opposed government-sponsored power projects. ${ }^{30}$ Other campaigns are directed at

Contributions by regulated corporations to organizations dedicated to influencing the political process may be disallowed for rate-making purposes. E.g., In the Matter of Alabama Power Co., F.P.C. Opinion No. 337 (Aug. 17, 1960).

20. See Egan v. United States, 137 F.2d 369, 374 (8th Cir. 1943), cert. denicd, 320 U.S. 788 (1943).

21. Heard, The Costs of Democracy 134, 237 (1960) [hereinafter cited as Heard.

22. Id. at $134,239$.

23. Id. at $237-38$.

24. Hearings Before Senate Subcomnittee on Privileges and Elections of the Committee on Rules and Administration to Investigate the 1950 Ohio Senatorial Campaign, 82d Cong., 1st \& 2d Sess. 180-82, 424 (1952); Bicks \& Friedman, Regulation of Fedcral Election Finance: $A$ Case of Misguided Morality, 28 N.Y.U.L. REv. 975, 995 \& n.7 (1953).

25. Questionnaire.

26. See Baumer \& Herzaerg 130; Bart, supra note 1.

27. See authorities cited note 19 supra. Policies of the organization, however, may at times differ from that of the corporation. See Taft, supra note 1.

28. Gulf Program.

29. For descriptions of the natural gas companies' campaigns, see Ross, The Image Merchants 20 (1959); Senate Hearings Before the Special Committee to Investigat: Political Activities, Lobbying and Campaign Contributions, Oil $\mathcal{G}$ Gas Lobby Investigation, 84th Cong., 2d Sess. (1957).

30. See N.Y. Times, Jan. 21, 1961, p. 32, col. 5; In the Matter of Alabama Power Co., F.P.C. Opinion No. 337 (Aug. 17, 1960). Thirty-five companies spent just under 
measures or political attitudes having an impact on business generally. ${ }^{31}$ Labor reform, ${ }^{32}$ inflation, ${ }^{33}$ free enterprise, ${ }^{34}$ and "right-to-work" laws ${ }^{35}$ exemplify these objectives. Legislation having no direct impact upon business, such as old age health assistance plans ${ }^{36}$ aid to public education ${ }^{37}$ and subversive control activities ${ }^{3 s}$ have also been the objective of business campaigns. Finally, corporations have sought to influence the outcome of local political struggles, campaigning in favor of issues such as school improvement ${ }^{39}$ and consumer credit reporting statutes. ${ }^{40}$

Most literature in this area claims that the programs are "nonpartisan." 41 The stands taken on highly controversial issues such as right-to-work laws or medical care for the aged ${ }^{42}$ indicate that "nonpartisan" is used in its narrowest sense. In some cases, moreover, companies have admitted exerting influence over local and national elections. ${ }^{43}$ And while get-out-the-vote propaganda need not favor one party, it can be so administered. ${ }^{44}$

At least in some instances, the corporation's political ideas are sold with the same public relations techniques used to sell its products. Those claiming

$\$ 2,000,000$ on the "Electric Companies Advertising Program." Id. at 3. For examples of their publicity, see $i d$., appendix A.

31. See Mitau, Control ozer Canpaign Finance, 23 U. CHr. L. Rev. 620, 636 (1956). See also Baumer \& Herzberg 23 ("business climate" advertising).

32. Questionnaike. One company fought a New Jersey law which would have paid unemployment benefits to strikers. BAUMrer \& HerzBerg 22.

33. E.g., The Atlantic, Feb. 1960, p. 95 (advertisement) ; Baumar \& Herzberg 22; QuestronNaIre (fifteen companies had anti-inflation programs).

34. For a critical analysis of the free enterprise campaign, see WHYTE, Is ANyBody LISTENrNg? 1-20, 29 (1952) (questioning the reality of a serious threat of socialist success in the United States). One purpose of corporate political programs is to fight socialism. Eaumer \& Herzberg 73.

35. Letter to George B. Driesen From E. Jagust, Share Owner Relations Dept., General Electric Co., (June 11, 1959), on file Yale Law Library.

36. See Bart, supra note 1; Kempton, Don't Write-Telegraph, N.Y. Post, Aug. 25, 1960 , p. 37 , col. 1 .

37. See Bart, supra note 1.

38. Questionnatre.

39. See State v. Cleveland-Cliffs Iron Co., 169 Ohio St. 42,157 N.E.2d 331 (1959);

Questionnaire; Baumer \& Herzberg 23.

40. Questionnaire.

41. See Gulf Program p. 6; Baumer \& Herzberg 30-33; Scott Paper Co., Our Responsibilities in Political Affairs in Official Program, 1960 Democratic National Convention, p. 79. See also Krock, Business Men As Agents of Public Policy, N.Y. Times, October 30,1959 , p. 26, col. 4.

42. See notes 35,36 supra.

43. One G.E. plant manager gave his company's political education program credit for the overwhelmingly favorable voter response in Syracuse, N.Y., to Vice-President Nixon and defeat of an incumbent Congressman. Companies' Role in the Election, Business Week, Nov. 26, 1960 , pp. 34, 36.

44. See, e.g., Unions Enter Political Arena With Drive to Get Out The Vote, Business Week, Aug. 27, 1960, pp. 108, 110. 
the ability to engineer consent have described their methods in detail. ${ }^{40}$ The "public" most likely to influence those with whom the power of decision lies must be identified. A substantial percentage of that public must initially be either uncommitted or favorably disposed to the corporation's view-point if the campaign is to be successful. Having selected the relevant "public," the public relations expert must ascertain its dominant aspirations and prejudices. By the use of themes and symbols likely to appeal to these attitudes, a favorable group consensus can be created. To supplement the "engineering of consent," an appearance of public support may be simulated through third party techniques-the formation of purportedly independent civic and educational organizations which lend their support to the campaign. ${ }^{47}$

\section{Political Education of Employees}

In order to stimulate the political interest of employees and to encourage managers publicly to express their views, a few corporations have recently inaugurated political training courses. ${ }^{48}$ Often they are held during business hours. ${ }^{49}$ Most of these courses are based upon a series of pamphlets prepared for this purpose by the United States Chamber of Commerce. ${ }^{50}$ Discussion conferences led by teachers, local politicians, and employees develop the ideas contained in these pamphlets. In one case discussions and workshops are keyed to motion pictures, prepared for the company by a university, in which experts describe the federal constitutional system, the role of the Supreme Court, the need for individual political action, the function of pressure groups, campaign

46. See Bernays, The Engineering of Consent 11, 29, 31-32, 54-93, 13\$-55 (1955). For examples of effective, albeit oftentimes misleading, use of symbols by PR technicians, see Ross, The Inage Merchants 70, 75, 76, 80 (1959).

47. See, e.g., Hearings Before the Special [Senate] Committee to Investigate Political Activities, Lobbying and Campaign Contributions, 84th Cong., 2d Sess. $613-40$ (1957); Noerr Motor Freight, Inc. v. Eastern R.R. Presidents Conference, 155 F. Supp. 768 (E.D. Pa. 1957), aff'd per curiam, 273 F.2d 218 (3d Cir. 1959), rev'd, 29 U.S.L. WeEK 4191 (Sup. Ct., Feb. 20, 1961), Note, 70 Y ALE L.J. 135, 138 \& n.28 (1950); Ross, op. cit. supra note 46, at 109-24. Lower courts in Noerr held these tactics beyond the pale of constitutional protection, against public policy, and illegal. The Supreme Court reversed.

48. Questionnaire; Baumer \& Herzberg 46, 109-14. All but one of the programs described by respondents to the Questionnaire were initiated in 1959 or 1960.

On the effectiveness of these programs in stimulating employee political participation see BaUMer \& HerzBerg 118-20; Companies' Role in the Election, Business Week, Nov. 26,1960, p. 34.

49. Nine companies hold classes during business hours; seven do not. QUESTIONNAIRE. One of the advantages of evening classes is that wives may attend.

The most ambitious program reported required 30 hours; two companies had a series of classes aggregating eight hours. The median number of hours was sixteen. QUESTIONNAIRE.

50. Questionnatre. The Chamber course is described in Bauner \& Herzberg 11314. See also Barnett, Politics Given 'Shot in Arm' by Business, New Haven Evening Register, May 5, 1960, p. 62, col. 8. 
techniques, and the like. ${ }^{51}$ Of the companies which responded to the Questionnaire, slightly more than half permit employees on all levels to participate; the others at present restrict enrollment to salaried and supervisory personnel. ${ }^{82}$

\section{Released Time}

To permit employees actively to participate in political campaigns, a few companies have adopted an express policy permitting absences during regular business hours. ${ }^{53}$ Responses to the Questionnaire showed that six of the nine companies which permit such absences compensate the employee for the time spent in political activity. ${ }^{54}$ Only one company extended the "released time" privilege to production line employees, the rest granting absence only to supervisory and salaried personnel. ${ }^{55}$ Several companies encourage their employees to seek political office. Staff and management employees are granted leaves of absence with or without pay (depending upon the term of the office) and, where applicable law permits, without loss of vacation privileges, service awards, insurance, and other "fringe benefits." 6

\section{Impact of Corporate Political Programs}

\section{The Corporation}

A company's political persuasion program may be an important factor in its economic success. The ability to generate public support may be used defensively-to resist government measures likely to decrease profits-or offensively-to secure adoption of measures which will assist the company to increase its income.

51. The company's description of its course indicates that it offers employees a rather sophisticated introduction to civics and government along with instruction in the practicalities of politics. Less emphasis on "practical politics" and greater attention to the complex nature of the problems facing government and the tools with which it solves them has been suggested by critics. See Reagan, The Seven Fallacies of Business In Palitics, 43 HARv. Bus. Rev. 60, 64-65 (1960); Taft, supra note 1, at 65.

52. Several companies expressed an intention to broaden participation in the future.

53. Nine companies have such policies. Most have been initiated since 1957. QuEsTIONNArRE. In addition, officers of some corporations devote full time to their company's political interests. HEARD 133 ; see Taft, supra note 1 , at 10.

54. One important industrial corporation pays hourly rated employees for part-time political activity at the rate they would be have earned on the job. Employees must first attempt to be placed on a shift that will not conflict with their political duties. National Industrial Conference Board, Proceedings of the Conference on Company Participation In The Political Process (March 17, 1960). None of the companies account separately for this compensation and thus the cost of this program, like others discussed in this Comment, is not known by management. QUESTIONNAIRE.

55. QUestionnaIRE.

56. Statements of policy supplied by respondents to Questionnaire. These statements indicate an awareness of the problems posed by Corrupt Practices Acts and Conflict of Interest statutes. 
Released-time programs may also improve a corporation's profit picture. By permitting employees to serve in elective and appointive positions, the corporation may secure public contracts not otherwise available to it. $A$ former employee will be familiar with the capabilities of the corporation and will therefore be likely to recommend its services to governmental officials. ${ }^{57}$ Such an employee can also serve as a source of information concerning government projects of which the company may be unaware. When the released-time program makes possible the election of former employees to public office, moreover, the corporation may secure direct representation for its point of view in state, federal, or local legislatures. ${ }^{58} \mathrm{~A}$ former employee can be expected to remain sympathetic to the views of the corporation which employed him and from which he may continue to receive some benefits while in office. ${ }^{59}$ Even when such beneits are terminated during his term of public service the employee may look foward to a return to his former role with the company. Released-time programs may also create good will in local communites where company facilities are located by demonstrating the corporation's concern for the well-being of the community. ${ }^{60}$

Political training programs supplement the benefits provided by releasedtime policies by increasing the probability that managerial employees will become instrumental in the formulation of party policy and will be elected or appointed to governmental positions.

Corporate political programs are not without costs and dangers. Managerial and financial resources appropriated for political activity are diverted from alternative pursuits which might be more profitable. ${ }^{61}$ And if the corporation

57. See Hearings Before the Permanent Subcommittce On Investigations of the Senate Committee On Government Operations Concerning Harold E. Talbott, Secretary of the Air Force, 84th Cong., 1st Sess. (1955). The official involved resigned.

58. See Baumer \& Herzberg 78.

59. See Conflicts of INTERest 20. Continuation of benefits may be prohibited for some offices by conflict of interest legislation, and companies are generally aware of this limitation. See note 56 supra.

60. Local affairs are emphasized. See QuEsTronNaIRE (supplemental materials) ; GuLF Program 4. But see Taft, supra note 1 , at 64 .

61. One company's policy memorandum struggles with the problem as follows: Normally such activities will be on an individual's own time, on those occasions where he may find it necessary to request a reasonable period of time off for that purpose, his request will be granted if it does not conflict with the performance of his duties .... If the political office is of a part time nature that would normally require the individual's own time but on occasions may require him to request a reasonable amount of time off from his ... work, his supervisor will grant any such request if, in the supervisor's judgment, it does not conflict with the individual's responsibilities in the [company] or otherwise impede [its] operations.

An individual who is elected or appointed to any local or state legislative office and is required to be absent from the [company] in order to attend sessions of the legislative body of which he is a member, will continue to receive his full pay during such periods of absence provided such absences do not extend into a major portion of the calendar year. 
unsuccessfully attempts to defeat a candidate ${ }^{62}$ or vigorously opposes measures favored by one party, the victorious candidate or party might retaliate by instituting embarrassing investigations of the corporation's business or by supporting legislation hostile to its interests. A pronounced political coloration involves other disadvantages. Persons whose political convictions are antithetical to those of the company may find the climate created by its programs uncongenial and may refuse to accept employment. ${ }^{63}$ Finally, state conflict of interest laws may deprive companies whose employees are public officials of profitable business opportunities and other benefits. Common law rules, ${ }^{64}$ statutes, ${ }^{65}$ and local ordinances ${ }^{66}$ prevent employees ${ }^{67}$ and shareholders ${ }^{68}$ from participating in the quasi-judicial decisions of state and local governments benefitting their employer. Under the heading of quasi-judicial decision, courts include contract awards, ${ }^{69}$ grants of privileges, ${ }^{70}$ and tax benefits. ${ }^{71}$ In some states the mere participation of an employee in the decisional process voids an action benefitting his employer. ${ }^{72}$ On the other hand, a few states will void the transaction only if the employee casts a deciding vote. ${ }^{73}$ The majority, however, will strike down the transaction if an employee has cast a ballot regardless of the margin by which it passed. ${ }^{74} \mathrm{~A}$ conflict of interest

62. Several companies reported they had sought to help elect candidates by using the communications media described in the Questionnaire.

63. The competition for capable management personnel is very keen. A company can lose key personnel by a comparatively noncontroversial get-out-the-vote campaign. See Companics' Rale in the Election, Business Week, No. 20, 1960, p. 34. See also Taft, Should Business Go In For Politics?, N.Y. Times Magazine, Aug. 30, 1959, p. 64 (business in politics campaign looks like it is against all progress).

64. See generally 4 Scotr, Trusts $\$ \$ 496-503$ (2d ed. 1956); 2 DILLON, MUUNICIPAL Corporations $\$ 773$ (5th ed. 1911).

65. Grady v. Livingstone, 115 Mont. 47, 141 P.2d 346 (1943) (discussing several statutes).

66. See, c.g., Buffington Wheel Co. v. Burnham, 60 Iowa 493, 15 N.W. 282 (1883).

67. See, c.g., Stockton Plumbing \& Supply Co. v. Wheeler, 68 Cal. App. 592, 601-02, 229 Pac. 1020, 1024 (Dist. Ct. App. 1924). Contra, County Ct. v. Grafton, 77 W. Va. 84, 86 S.E. 924 (1915).

63. Foster v. Cape May, 60 N.J.L. 78, 36 Atl. 1089 (Sup. Ct. 1897) ; Note, 12 Rutgers L. Rev. 582, 589-90 (1958) ; Annot., 140 A.L.R. 344 (1942) (collecting cases). One commentator has questioned the wisdom of applying this rule when the stock is publicly held. Note, 107 U. PA. L. Rev. 985, 993 (1959).

69. See Miller v. City of Martinez, 28 Cal. App. 2d 364, 82 P.2d 519 (Dist. Ct. App. 1938); Grady v. Livingstone, 115 Mont. 47, 141 P.2d 346 (1943).

70. Pyatt v. Mayor and Council of Dunellen, 9 N.J. 548, 89 A.2d 1 (1952) (Brennan, J.) ; Annot., 133 A.L.R. 1257, 1263-64 (1941) (collecting cases). Issuing a license is also a quasi-judicial act. Compare City of Miami Beach v. Schauer, 104 So. 2d 129 (Fla. Ct. App. 1958) (zoning ordinance not quasi-judicial).

71. The conflict would arise through participation in tax appraisals of property.

72. Pressey v. Hillsborough, 37 N.J. Super. 486, 117 A.2d 646 (App. Div. 1955) cortif. denied, 20 N.J. 303, 119 A.2d 789 (1956) (participation in deliberation). Compare, Note, 12 Rutgers L. Rev. 582, 594 (1958).

73. See Annot. 133 A.L.R. 1257, 1263-64 (1941).

74. Miller v. City of Martinez, 28 Cal. App. 2d 364, 82 P.2d 519 (Dist. Ct. App. 1938); Mills v. Town Plan Comm'n, 144 Conn. 493, 134 A.2d 250 (1957) ; Rollin v. Connor, 74 N.H. 456, 69 Atl. 777 (1908). 
deprives a corporation not only of the benefit of its contract, but also, in most states, of any recovery in quasi-contract for goods or services supplied..$^{75}$ In addition, an employee who has improperly participated in such a transaction may be subjected to criminal sanctions. ${ }^{78}$

\section{The Employee}

Training in practical politics and in the history and function of democratic institutions will broaden the employee's understanding of the society in which he lives. And if an employee long interested in political activity or newly stimulated by the training he has received wishes to participate in "politics," released-time programs and explicit company approval will encourage him to do so. ${ }^{77}$ These activities, in turn, enable an employee to make personal contacts and to develop speech techniques, organizational ability, and other political skills which will prove useful in his work for the company. ${ }^{78}$

But the impact of a corporation's political program upon an employee might well be adverse. If, as a result of his election to public office, he incurs liability under a conflict of interest statute ${ }^{79}$ or he is forced to divest himself of stock holdings in the company, ${ }^{80}$ his financial well-being may be impaired. More significantly, these programs could threaten political independence of some employees. An official company attitude toward legislative or ideological questions might be transmitted to persons with promotional authority who could make acceptance of these attitudes a factor in hiring and advancement. ${ }^{81}$ Employees may be particularly vulnerable to coercive pressures when political

75. Miller v. City of Martinez, supra note 74. This is the majority rule, see Grady v. Livingstone, 115 Mont. 47, 65, 141 P.2d 346, 355 (1943) (dissenting opinion). Contra, Grady v. Livingstone, supra. For a detailed discussion, see Lillich, Muticipal Conflicts of Interest: Rights and Remedies Under an Invalid Contract, 27 FORDHAM L. REv. 31 (1958).

76. E.g., N.J. Rev. Stat. § 2A:135-8 (1953); Fla. Stat. ANN. § 839-09 (1944); Note, 107 U. PA. L. Rev. 985, 988 \& n.16 (1959) (collecting statutes). On the federal statutes, see McElwain \& Vorenberg, The Federal Conflict of Interest Statutes, 65 Harv. L. Rev. 955 (1952); Davis, The Federal Conflict of Interest Laws, 54 Colun. L. Rev. 893 (1954). "Anyone who takes a job in Washington may be relying on a lawyer's bad guess, and . . . may end up in the penitentiary-at least in theory." Solow, Conflict of Interest: $A$ Legal Nightmare, Fortune, Jan. 1961, p. 97-99. For a general analysis of the statutes, see CoNflict of INTEREst 36-71. The statutes, both state and federal, are badly in need of overhaul. Id. at 180-84. See Kaplan \& Lillich, Municipal Conflicts of Interest, 58 CoLun. L. Rev. 157, 181-82 (1958) ; Solow, supra at 97, 99.

77. These programs have apparently been successful in inducing employees to run for office and to assist their parties. See Companies' Role in The Election, supra note 63; BaUmer \& Herzberg 131.

78. Barnett, Politics Given 'Shot In Arm' by Business, New Haven Evening Register, May 5, 1960, p. 62, col. 8. The problems facing modern management, moreover, are said to be primarily political. Berle, Power Without Property 67-68 (1959).

79. See note 76 supra.

80. Although not required by statute, divestment has been a problem for corporate officers entering the federal service. See, e.g., Conflicts of INTEREst 96.

81. Promotion to high positions in the corporate hierarchy is said to be almost entirely dependent upon "acceptability." MmLs, The Power Elite 141, 142, 144 (1956). See 
training sessions are conducted by company personnel. ${ }^{82}$ Pressure to conform to these company attitudes may exist even if top management does not consciously intend to impose its will upon junior executives. As a result of his desire to conform to corporate norms, the employee may feel compelled to suppress his other extracurricular interests in order to participate actively in politics after business hours ${ }^{83}$ or to disassociate himself from political ideas or organizations which he believes are disapproved. ${ }^{84}$ Finally, recent psychological studies indicate that when an individual feels compelled to pretend acceptance of an idea at variance with his privately held convictions, and does so for a reward he considers mean or inadequate, he will tend to alter his private convictions. ${ }^{85}$

\section{The Public}

Political training and released-time programs will also confer some benefits on the public. These programs, in so far as they make available to political

generally Berle, Power Without Property 79-80 (1959). Latham, The Body Politic of the Corporation, in Mason, The Corporation in Modern Society 230, 232 (1959). Presumably, organized employees will not be affected by company political pressures because promotion up to the level of foreman is often governed by contract.

States have passed statutes seeking, to a very limited extent, to prevent the employment relation from being utilized to compel political conformity. See, e.g., FLA. Stat. ANn. $\S$ 104.081 (1960) ; Mich. Stat. Ann. $\$ 6.1912$ (1956); Del. Code Ann. tit. 15, §§ 5161-63 (1953) ; Mrnn. Stat. AnN. 211.24 (1946).

82. Company personnel conducted political training classes for fourteen of the sixteen companies responding to the Questionnaire. There is no direct evidence of any attempts to utilize training programs to influence employee political views. But see, Companies' Role In The Election, supra note 63, at 36 (plant manager credits large majority for presidential candidate to "better political education") ; cf. BAUMER \& HERZBERg 28 (viewing political education of employees and propagation of management's ideas as part of same process).

83. One company's policy statement promises "employees are completely free to take part or not as they choose." QUESTIONNAIRE. But another provides, "[T] he program will ... insist that all Gulf personnel involved work with local political leaders and elected representatives. ... [I]ncentives need not be offered, but recognition of particularly outstanding ... political contributions by employees in Company publications will be made." Gurf Prograx 4, 6. Explaining how one company induced lower level management to take the course, the assistant director of advertising and public relations of Armstrong Cork Co. explained that there was no problem, "The President just said 'Everybody ought to." Barnett, Politics Given 'Shot in Arm' By Business, New Haven Evening Register, May 5, 1960, p. 62, col. 8. Wives are included in the company plans. Gulf Program 6; Baumer \& HERZBERG 32, 38.

Analogous problems have been created for employees by corporations embracing the virtues of civic participation, and charitable activities. See, Long, The Corporation, Its Satellites, and The Local Community, in Mason, The Corporation In Modern Society 211 (1959) (employees feel compelled to participate in civic affairs to assure promotion).

84. "Predominantly Republican management has instilled the fear of God in members of junior management who have an inclination towards the Democratic Party." OPINION Researce Corp., Realistic Policy For Business In Politics 31 (1959) (citing party leader).

85. See Note, 70 YaLE L.J. 298, 307 \& n.51 (1960). 
parties a pool of trained volunteer workers, will reduce campaign costs and lessen the dependence of parties and candidates upon wealthy individuals or institutions who may exert an unwarranted influence upon party policy. ${ }^{80}$ Reduced campaign expenses could promote more effective political opposition in some communities by enabling reform or independent groups to compete with better financed incumbent party organizations. Also, participants in company political training programs constitute a source of knowledgeable candidates. And these programs could lighten the financial burden of public service. At present, government is handicapped in the competition for highly skilled and talented manpower by the higher salaries offered by industry and business. ${ }^{87}$ Supplementing government pay-checks with corporate fringe benefits and assuring the employee of an opportunity to return to the company, so that his long-term career plans are not jeopardized, could partly off-set the effect of the salary differential. ${ }^{88}$

But the efforts of some corporations to encourage employees temporarily to enter public service also raises serious questions. In a legislature, federal or state, impartiality is neither expected nor desirable. Indeed, satisfactory resolution of conflicting interests can best be accomplished by a legislature whose members actively represent different groups within the electorate. ${ }^{80}$ One who is appointed to a government post, however, must serve the government's interests alone. If an appointee retains financial ties to the corporation, he may not be completely impartial when its interests indicate one decision and the "public interest" appears to compel another.90 And even if he were able to remain impartial while receiving or anticipating benefits from his former employer, public confidence in government will be impaired if its officers maintain bonds likely to generate conflicting loyalties. ${ }^{91}$ On the other hand, requiring employees to make a complete break with the company may not be advisable. A complete break, including a termination of salary and fringe benefits, sale of all the employee's stock in the company, and an

86. See Hearings Before the Special Committee to Investigate Political Activitics, Lobbying, and Campaign Contributions, 84th Cong., 2d Sess. 255-56 (1956) (statement by Walter Reuther).

87. See Conflicts of Interest 140-41. See also id. at 183.

88. See $i d$. at $141,183$.

89. See The Federalist, No. 10 (Madison); Conflict of Interest 14; MeikelJOHN, POLITICAL FREEDOM 81 (1960).

90. No dishonesty on the part of the employee-public servant need be implied to reach this conclusion; conflicting loyalties may prejudice the public interest. See People ex rcl. Schenectady Illuminating Co. v. Board of Supervisors, 166 App. Div. 758, 760, 151 N.X. Supp. 1012, 1014 (1915) (dictum) ; Kaplan \& Lillich, Municipal Conflicts of Interest: Inconsistencies and Patchwork Prohibitions, 58 CoLUM. L. REv. 157, 177-78 (1958); CoNFLICT OF INTEREST 144.

91. See Conflicts of INTERest 6-7.

Even if all benefits are terminated, an employee may retain an interest in the company inconsistent with devotion to public service. See Yonkers Bus Inc. v. Maltbie, 23 N.Y.S. $2 d 87$ (Sup. Ct.) (dictum), aff'd, 260 App. Div. 893, 23 N.Y.S.2d 91 (3d Dept. 1940). 
agreement not to rehire upon termination of government service, would solve the conflict of interest problem but might not be in the long run interest of the government. Qualified employees will be reluctant to enter government service, and corporations, willing to release employees temporarily but not to lose them permanently, would be unlikely to encourage them. A solution to these interacting problems of personnel and dual loyalities requires a careful selection of the benefits which employees entering government service can retain. The benefits allowed should probably differ according to the government position involved, and the efficacy of other measures, such as nonparticipation in certain decisions, in bringing about impartial administration. ${ }^{92}$

The legitimacy of political persuasion programs is also questionable. The objectives of these persuasion campaigns are not chosen by "the corporation" which is, after all, only a legal category of business organization. Political policy is made by the top officers or their delegees. ${ }^{93}$ Because of the dispersion of stock ownership and the apathy of most shareholders, these decisions are not subject to review and approval by the corporation's "owners." Nor is there review by the company's salaried employees, wage earners, and customers-other groups on whose behalf corporate officers are said to administer corporate assets..$^{94}$ As a result, the opinions of the corporation tend to be the personal opinions of its management. ${ }^{95}$

The unrepresentative power of corporate officials seems not to pose a serious problem to present day commentators, who tend to regard the notion of corporate democracy as obsolete. ${ }^{96}$ In part, this acceptance may be based

92. For a statutory solution to some of the problems, see CoNFLICT OF INTEREST 187-310.

93. Reification of "the corporation" is still common. See Hazard, It Takes Money to Get Elected, The Atlantic, Feb. 1960, p. 92. See also Dodd, For Whom Are Corporate Managcrs Trustees, 45 HARv. L. REv. 1145, 1154-55 (1932).

94. Just who should be included in the corporate "constituency" is the subject of some debate. Compare Dodd, supra note 93, at 1150 (shareholders, employees, customers and the public), and Boulware, Owners Can Help Themselves, Address Before American Society of Corporate Secretaries, June 8, 1960, pp. 4-5, with Rostow, To Whom and For What Ends is Management Responsible?, in Mason, The Corforation In Modern Society $68-69,71$ (1959).

95. For a recent example see Advertisement, The New York Times, April 26, 1960 (giving views of International Latex Corp. chairman on foreign policy).

If, as some observers have claimed, there is substantial unanimity of opinion among highranking corporate officials, cooperative use of corporate treasuries may give their point of view an excessive advantage in the clamor of competing ideas for public attention and acceptance. See Mirls, The Power Elite 122, 281-83 (1956) ; Ross, The Iarage Merchants 27, 34, 42 (1959) ; cf. Note, 66 HARv. L. Rev. 1259, 1260 (1953). But cf. Warner, The Corporation Man, in Mason, The Corporation In Modern Society 106-21 (1960). Compare Wormser, The Foundations: Therr Power and Influence 54-56 (1958) (warning of the danger of co-operation between foundations on political matters).

96. See Manning, Book Review, 67 YALE L.J. 1477 (1958). See generally Livingston, The Amferican Stockholder 20, $37-44$ (1958); Berle, Power Without Property 108 (1959). 
upon recognition that the corporation cannot be run democratically. But the present power of corporate officials also seems acceptable because it retains a certain legitimacy, based upon a belief that even with this power, management will administer corporate assets in the best interests of shareholders, employees, and others connected with the enterprise. ${ }^{97}$ In business affairs, a common interest in profits may assure beneficial administration, and the business expertise of management seems to justify abnegation of shareholder control. The recent legislative acceptance of corporate contributions to charity as proper ${ }^{98}$ may have similar foundations in the assumption of a common consensus to promote charity and a relative lack of controversy about the merit of one charity against another. Some political programs might also be found to accord with hypothesized preferences of those economically dependant upon the corporation. Something similar to the consensus about charity might legitimize political education. Even some choices on political issues-those having a direct relation to the corporation's earnings-might acquire a mantle of legitimacy on the basis of the shared motive of profits. This argument might logically be carried further to encompass all management decisions about politics or political ideologies. Any proposal which putatively improves the security, economic welfare, or social stability of the nation-or indeed the world-has some relation to profits. Some managers have accepted the doctrine that corporations have a responsibility to make their views known on all important issues which affect the national welfare, ${ }^{90}$ and this view is seconded by many others who believe that corporate assets must be administered, not only for the shareholders, but for the good of the community. ${ }^{100}$ But when management purports to speak for the corporation, with corporate assets, on matters of public welfare, the premise of an underlying consensus would seem to break down. Public welfare is a matter of basic values, on which shareholders and employees in a publicly held corporation can be expected to differ. And except for political proposals directly affecting the industry, management cannot be considered expert in these affairs. The legitimacy of political persuasion campaigns might also be undermined by a more fundamental objection to the notion of corporate executives acting as political trustees. Whatever the legitimacy of delegating control over wealth for profit or to satisfy charitable instincts, the democratic political process seems devoted to the idea that each individual must choose for himself the values he supports. ${ }^{101}$

The endocratic corporation's political activity might also be attacked in terms of its effect on the whole political process. The disturbing thought is

97. Cf. id. at 99-103.

98. Seee generally Prunty, Love and the Business Corporation, 46 VA. L. REv. 467 (1960).

99. See, e.g., Advertisement by Scott Paper Co., "Our Responsibilities In Political Affairs," Official Program, 1960 Democratic National Convention, p. 79.

100. See authorities cited note 6 supra.

101. Cf. United States v. International Union United Automobile Workers, 352 U.S. 567, 575 (1957) (dictum) (Frankfurter, J.). 
that a few individuals can mobilize the enormous resources of the endocratic corporation behind propositions they advocate. This attribute is not peculiar to the endocratic corporation; it is common to any great aggregation of wealth controlled by a few persons that may be used for political or ideological persuasion-large closely held corporations, unions, nonprofit foundations, and family fortunes to name a few. In searching out the reasons for disquietude about this phenomenon, several problems must be distinguished. First there is the problem of wealth itself. In the field of electioneering, candidates and sometimes parties are often limited to a certain amount of total expenditure. ${ }^{102}$ The limitation seems to be based on a belief that, while a certain amount of money may be necessary to inform the electorate about a candidate or party, money spent beyond that point serves only to enable one faction to out-shout the other. A necessary premise, it seems, is that the electorate will respond irrationally to too much propaganda. This premise, if true, can be applied to any campaign of political or ideological persuasion. Admittedly corporations are only one of many sources of wealth, and the amounts they spend on political persuasion is not generally known; even corporate officials claim ignorance, because political expenses are not separately accounted for. ${ }^{103}$ But because endocratic corporations do have potentially enormous resources and because they are demonstrably interested in political persuasion at the moment, concern for limiting the use of their wealth may be justified.

A separable problem is the feeling that, whatever the absolute limit on the amount spent, it is improper to allow it to be spent by the unrepresentative few, the negative pregnant being that the same expenditures would be proper if supported by the entire corporate constituency. The objection might be articulated as a feeling that it is undemocratic to allow a few persons to mobilize a great body of public opinion behind their personal views through the use of wealth. It may be this view, in part, which underlies corrupt practices legislation limiting the amount any individual or organization can contribute to an election campaign. If public support gathered in this way is presumed rational, however, the objection seems to evaporate. Indeed, the use of wealth might be lauded because it facilitates the effective dissemination of ideas among the electorate. ${ }^{104}$ The premise of this objection must be, therefore, that public opinion can be swayed by the application of costly public relations techniques regardless of the merits of a proposal, or that these techniques can create an appearance of public support in the eyes of responsible officials. ${ }^{105}$ This objection, however, also applies to any political organization whose members agree to pool their funds in an effort to generate

102. See generally Lucas, The Strength of Ten: Three-Quarters of a Century of Purity in Election Finance, 51 Nw. U. L. REv. 675 (1957) (discussing statutes).

103. QuestionNaire.

104. See Bicks \& Friedman, Regulation of Federal Election Finance: A Case of Misguided Morality, 28 N.Y.U.L. Rev. 975 (1953).

105. See Noerr Motor Freight, Inc. v. Eastern R.R. President's Conference, 29 U.S.L. WeEK 4191 (Sup. Ct. Feb. 20, 1961), Note, 70 Y ALE L.J. 135, 147-49 (1960). 
public support. If its campaign succeeds, the real or apparent public support created will still be disproportionate to the number of initial supporters. The view that democratic groups will foster a more democratic process is supportable only if one distrusts votes influenced by mass media campaigns and counts political support only by counting votes gathered without that influence. Rather than press this view any further, it seems wiser to conclude that the objection against control by the few is really an objection to the techniques one thinks they will use. This view may be especially prevalent with regard to corporations, whose use of mass persuasion techniques is well known.

\section{Existing Control Mechanisms}

As the above analysis indicates, corporate political programs benefit employees, shareholders, and the public but also create serious problems affecting all three groups. This section will examine the efficacy of three existing mechanisms-corrupt practices acts, shareholder proposals, and derivative suits-as devices to protect these various interests by limiting, in different ways, management's unrestricted political programs.

\section{Corrupt Practices Legislation}

The Federal Corrupt Practices Act ${ }^{106}$ and analogous statutes in thirty-six states ${ }^{\mathbf{1 0 7}}$ are the principal legal controls over management's right to use corporate assets for political purposes. These statutes are designed to protect the integrity of the political process from the harmful impact of large aggregates of wealth. ${ }^{108}$ At the same time, recognizing the nonrepresentative nature of the relationship between management and shareholders, the statutes attempt to protect stockholders from having "their" assets used in support of candidates or parties they might oppose. ${ }^{109}$

To achieve these goals, state and federal statutes prohibit corporate financial support of political parties and candidates. These restrictions were first

106. 62 Stat. 723 (1947), 18 U.S.C. 610 (1958).

107. The state statutes are collected in The Library of Congress Legrsiatrve Reference Service, Legal Restraints on Political Activities of Corporations 14-52 (Aug. 4,1958 ) and Ford, Regulation of Election Finance Table I, (Univ. of Cal. Bureau of Public Administration and Legislative Problems, No. 6, 1958).

108. See United States v. CIO, 335 U.S. 106, 113 (1948) ; United States v. Painters' Local, 79 F. Supp. 516, 519 (D. Conn. 1948), rev'd on other grounds, 172 F.2d 854 (2d Cir. 1949); State ex rel. La Follette v. Kohler, 200 Wis. 518, 560, 228 N.W. 895, 912 (1930) ; 65 Cong. Rec. 9507-08 (1924) ; Bottomly, Corrnpt Practices In Political Campaigns, 30 B.U.I. Rev. 331, 372 (1950).

109. See United States v. CIO, supra note 108; Hearings Before the House Committee On The Election of the President, 59th Cong. 1st Sess. 76 (1906) ; 40 Cong. Rec. 96 (1906). The interest of shareholders was a factor in the common law no-contributions rule. See People ex rel. Perkins v. Moss, 187 N.Y. 410, 439, 80 N.E. 383, 393 (1907).

Another objection to corporate participation in politics was that they lack a sense of "individual responsibility" and are motivated solely by profit and loss considerations. State v. Joe Must Go Club, Inc., 220 Wis. 498, 70 N.W.2d 681, 684 (1955) (dictum). 
enacted in the beginning of the twentieth century. The federal statute, the product of public furor created by revelations of the role corporations had played in financing the 1896 presidential campaign and fanned by President Theodore Roosevelt, was enacted in 1907.110 The New York statute, passed in 1906, was the result of similar pressures. ${ }^{111}$ An investigation revealed that some New York legislators had, in return for large campaign contributions by insurance companies, been consistently protecting their interests in the state legislature. ${ }^{112}$ And evidence was adduced showing that party bosses often exacted campaign contributions from corporations in exchange for franchises and other governmentally dispensed privileges. ${ }^{1 \times 3}$ Similar corrupt practices acts were subsequently passed by other states.

A typical statute provides:

No corporation whatsoever shall pay or agree to pay or contribute or consent to contribute, directly or indirectly, any money, property or other thing of value to any political party, organization, committee or individual for any political purpose, whatsoever, or for the purpose of influencing registration of any kind, to promote or defeat the candidacy of any person for nomination, appointment or election to any political office. ${ }^{114}$

While some of these statutes limit the prohibition to assistance to parties and candidates, several, including the Florida statute cited above prohibit expenditures for any political purpose whatever. ${ }^{115}$ All Corrupt Practices Acts impose criminal sanctions upon the directors and officers who authorized the prohibited acts, typically a fine of $\$ 500$ to $\$ 1,000$ and jail sentences up to one year. ${ }^{116} \mathrm{In}$ addition, several provide for dissolution of the corporation or withdrawal of the right to do business within the state. ${ }^{117}$ Primary responsibility for enforcement of these criminal statutes rests with state prosecuting officials. In most states, the prohibition against corporate campaign gifts is part of a more comprehensive scheme limiting the amount that may be contributed by one person to a candidate or political committee or ex-

110. 34 Stat. 814 (1907). For the background of the statute, see SikEs, STATE AND Federar Corrupt Practices Legislation 18S-92 (1928) ; United States v. UAW, 352 U.S. 567, 570-75 (1957). President Roosevelt's speeches are printed in 40 CoNG. REC. 96 (1905). See also 41 CoNG. Rec. 22 (1906).

111. N.Y. Sess. Laws, 1906, ch. 839, as amended, N.Y. PeNaI Law $\$ 671$ (1960 Supp.).

I12. See SrKES, op. cit. supra note 110, at 108-13.

113. Ibid.

114. Fla. Stat. AnN. $\$ 104.091$ (1960).

115. E.g., CoNsN. GEN. STAT. REv. § 9-339 (1958) bars corporations from promoting any "political party or principle." Other statutes are almost as broadly worded. E.g., N.Y. PeNAL LAW $\$ 671$ (Supp. 1960), discussed infra in note 126.

116. See e.g., Conn. Gen. Stat. Rev. § 9-345 (1958); Mp. Ann. Code art. 33, § 229 (1957) ; Mass. AnN. Laws ch. 55, $\$ 7$ (1953).

117. See, e.g., Kr. Const. $\S 150$; Mrnn. Stat. Ann. $\S 211.27$ (1946). In some states, if a candidate receives aid from a corporation he forfeits his election. WIs. Stat. Ann. $\S 12.24(1960)$. 
pended by any candidate in the course of an election. ${ }^{118}$ Most states require reports of the sources of a candidate's campaign funds and the uses to which they were put, either as a subsitute for or a supplement to the dollar limitation. ${ }^{119} \mathrm{~A}$ few states regulate the specific kinds of expenditures a candidate may make. ${ }^{120}$

In recent years, Corrupt Practices Acts have been subjected to increasingly virulent attack by commentators, who have cast considerable doubt on both assumptions which underlie these Acts: first, that legislators represent an identifiable "public interest," 121 and second, that they will be unable to do so unless the sources of their campaign funds are carefully regulated.122 Despite this criticism, however, the Corrupt Practices Acts remain as a serious threat to developing programs of corporate political action.

In addition to prohibiting direct contributions to political parties and candidates, corrupt practices acts may be construed to cover corporate efforts to stimulate popular support for governmental policies and legislation. The first issue in construing such statutes would be whether the state law in questtion applies only to attempts to influence the outcome of elections, or whether it includes attempts to persuade legislatures and government officials as well. Some statutes prohibit expenditures for "political purposes," while another forbids promotion of any "measure."123 Verbal interpretations of "political purpose" vary, ${ }^{124}$ but no reported case has been found under these statutes, involving a corporation, in which attempts to influence an election were not at issue. ${ }^{125}$ Most statutes also refer to contributions to some organization,

118. See generally, Ford, op. cit. supra note 107, at 1-9.

119. See generally $i d$. at Appendix, Table IV; Note, 40 MIINN. L. Rev. 156 (1956).

120. See FoRD, op. cit. supra note 107 , at 3-4.

121. Lucas, The Strength of Ten: Three-Quarters of a Century of Purity in Election Finance, 51 Nw. U. L. Rev. 675, 690 (1957) ; Shannon, The Political Process in Kentucky, $45 \mathrm{Kr}$. L.J. 395, 442 (1957) ("politics is the organization of hatreds").

122. Compare United States v. Painters Local, 79 F. Supp. 516, 521 (D. Conn. 1948), rev'd on other grounds, 172 F.2d 854 (2d Cir. 1949), with Bicks \& Friedman, Regulation of Federal Election Finance: A Case of Misgnided Morality, 28 N.Y.U.L. Rev. 975, 983-84 (1953), and HeARD 36-67; 90-94; 139-41.

123. See, e.g., Conn. Gen. Stat. Rev. § 9-339 (1958); Ga. Code Anv. § 22-724 (1936) ; N.Y. PENAL LAW $\S 671$. The New Hampshire and Indiana statutes forbid corporate contributions to any political committee for the purpose of promoting any "measure." N.H. Rev. Stat. Ann. \$ 70:2 (Supp. 1960) ; Ind. Stat. Ann. \$29-5712 (1949).

124. The Wisconsin statute defines a "political purpose" as an intent to influence the outcome of any election. Wis. Stat. ANN. \$ 12.01 (1960). Similarly, in Green v. Cleveland, 33 N.E.2d 35, 37 (Ohio App. 1940), where a city employee was denied the right to work for a referendum proposing a city charter amendment, the court defined "political purpose" to include all attempts to influence the outcome of an election. But many states do not define the term. See, e.g., N.Y. Penal LAw \& 671; Ind. Stat. Ann. \$ 29-5701 (1949) ; Neb. Rev. Stat. Ann. \$ 32-1129 (1952).

125. See United States v. United States Brewers' Ass'n, 239 Fed. 163 (W.D. Pa. 1916) ; State v. Terre Haute Brewing Co., 186 Ind. 248, 115 N.E. 772 (1917) ; State v. McCrocklin, 186 Ind. 277, 115 N.E. 929 (1917) ; People v. Gansley, 191 Mich. 357, 158 N.W. 195 (1916) ; State v. The Cleveland-Cliffs Iron Co., 169 Ohio St. 42, 157 N.E.2d 331 (1959). 
often defined as a political organization. Contribution to a trade association which engages in support of candidates or legislation might be classified as "contribution to a political organization," depending on whether the state law's definition of "political organization" includes groups which have other functions which are nonpolitical. ${ }^{126}$ "Issue" advertising published by a corporation during an election campaign which directly paralleled the statements of candidates ${ }^{127}$ or party platforms could be construed to be a contribution of a "thing of value to [a] political party or . . . to a candidate for public office ..." 128 The crux of this interpretation is the concept of "contribution," the idea that the corporation contributes by performing a service, such as advertising, as well as by giving money. Statutes generally require that the contribution be "to a political organization," defined variously as an organization designed to influence elections or measures. This rationale might prohibit even independent advertising expressing views on legislative issues, provided the state statute reaches the influencing of legislation and that the corporation's advertisement was published to aid a "political organization" with a similar motive. The greatest problem here would be to determine whether the corporation's intent was to assist the political organization or to advocate the measure itself. In the light of the constitutional problems posed by these statutes, courts may be reluctant to permit a finding of intent to aid the organization.

The Ohio Corrupt Practices Act proscribes corporate political issues campaigns only if the particular issue supported or opposed is "partisan,"129 and a similar gloss has been added by judicial construction to other parts of corrupt practices legislation. ${ }^{130}$ The range of activities comprehended by the word "partisan" is unclear. An issue could be said to be partisan if

126. Some definitions are ambiguous. E.g., N.H. Rev. Stat. ANN. § 70:1 (Supp. 1960) ("any organization of two or more persons to influence elections or measures"). Quacre whether the corporation itself may not be a political committee within this definition. Other statutes have no definition. See, e.g., Wis. Stat. ANN. § 12.56 (1960). The New York statute forbids the use of corporate property for any political purpose whatsoever. N.Y. PENAL LAW \$ 671. No "contribution" of money or services seems required to bring corporate attempts to influence political decisions within the statute. If an intent to influence legislation is a "political purpose," this statute may even outlaw dissemination of management's views in stockholder reports and company newsletters. So construed, the statute may be an unconstitutional deprivation of free speech. See United States v. CIO, 335 U.S. 106, 121 (1948) (concurring opinion) (dictum).

127. See, c.g., Hearings Before the Senate Subcommittee on Privileges and Elections of the Committee on Rules and Administration to Investigate the 1950 Ohio Senatorial Campaign, 82d Cong., 1st \& 2d Sess. 180-82, 424 (1952) ; Bicks \& Friedman, supra note 122, at 995 \& n.7; Mitau, Selected Aspects of Centralized and Decentralized Control Over Campaign Finance: A Conmentary on S. 636, 23 U. CHr. L. REv. 620, 636 (1956).

128. Fra. Stat. AnN. $\$ 104.091$ (1960). But see Smith v. Higinbotham, 187 Md. 115, 130-31, 48 A.2d 754, 761 (1946).

129. OHIo Rev. Code ANN. §3599.03 (1954).

130. See, e.g., Heidtman v. City of Shaker Heights, 163 Ohio St. 109, 119 N.E.2d 644 (1954); Commonwealth v. McCarthy, 281 Mass. 253, 183 N.E. 495 (1932). 
national' party platforms differ on the matter. But this standard would appear irrelevant in a one-party state or in a primary election unless the party itself is split on the issue. The meaning of "partisan" is unclear where a particular point of view has not been included in one party's platform but a position has been taken on the matter by the other, or both major parties agree but are opposed by "splinter" parties. Further, the effect of statements by party leaders, minor officials, and candidates about an issue upon its partisan or nonpartisan character is difficult to define.

The one court which has faced these questions did not resolve them. In Siate v. Cleveland-Cliffs Iron Ore Corp., ${ }^{131}$ the Prosecuting Attorney of Cuyahoga County brought a quo warranto action based on defendant's contribution of $\$ 500$ in corporate funds to a Citizens Committee For City and County Issues, with the understanding that the funds would be used to support several local bond issues and a home rule amendment to the Ohio constitution. The court construed partisan political purpose to exclude "a purpose merely to advocate the adoption of a constitutional amendment or the passage of a bond issue or of a tax levy . . .,"132 but failed to articulate a meaningful definition of "partisan." Indeed, the court revealed a reasonable doubt as to whether the legislature intended a broad or narrow definition, and decided the case on the basis of the general rule of construction which resolves doubts in interpretation of a criminal statute in favor of the defendant. ${ }^{133}$

Corporate released-time programs under which employees continue to receive pay while doing political tasks could also be held to violate the Corrupt Practices Act. A few of these statutes specifically proscribe the contribution of employee services to a political party. ${ }^{134}$ And it is implicitly proscribed by state statutes which prohibit the contribution of money, property, or a thing of value to any political party, candidate, or committee. ${ }^{135}$ The services of an employee clearly represent a "thing of value" to the corporation, and to the political party. On the other hand, so long as the initiative to participate comes from the employee, and party affiliation is not a consideration in determining which employees may be compensated for their political efforts, courts would probably not sustain an indictment against the corporation. This result could be supported on grounds of benefit to the public from increased participation throughout the political process. The nar-

131. 169 Ohio St. 42,157 N.E.2d 331 (1959).

132. 169 Ohio St. at 45,157 N.E.2d at 336 .

133. 169 Ohio St. at $45-46,157$ N.E.2d at 334 .

134. See, e.g., Minn. Stat. Ann. § 211.27 (1945) ; Mississippi specifically prohibits compensation of employees for participating in primary campaigns. Mrss. CoDE ANN. $\S 3172$ (1956). See also N.H. Rev. StAT. ANN. § $70: 1$ (V) (Supp. 1959) ("thing of value shall not include services of volunteers who receive no pay therefor").

135. See, e.g., N.D. Century Code Ann. $\$ 16-20-08$ (1960); Orla. Stat. Ann. tit. $26 \S 439$ (1951). The federal statute appears to have been construed to the contrary. United Stațes v. Constr, Local, 101 F. Supp. 869 (W.D. Mo, 1951). 
row construction could be rationalized by coupling the doctrine that doubts concerning the meaning of a criminal statute must be resolved against the state ${ }^{130}$ with the view that the employee, rather than the corporation, is here making the contribution.

Even though Corrupt Practices Acts could be construed to prohibit corporate political activities, it appears unlikely that they will significantly slow the trend toward increasing corporate participation in that area. The threat of active prosecution under these statutes is a paper tiger. ${ }^{137}$ Several factors might be hypothesized to explain almost complete lack of enforcement. As a tactical matter, prosecutors may be loath to institute actions because they fear that most juries will refuse to impose criminal sanctions on important corporations. ${ }^{138}$ Where a corporation provides a substantial percentage of local tax revenues and is a large employer of county citizens, its dissolution, permitted under some statutes, may be more disastrous than its continued political efforts. Many district attorneys, moreover, may have been elected with the help of funds contributed directly or indirectly by corporations or officials associated with them and would naturally be reluctant to bite the hands that feed. And even if the Corrupt Practices Act litigation were vigorously pressed against corporate political action it seems likely that corporations bent on politicking could devise ways to avoid detection. As has been noted above, corporations have purchased tickets to party fund-raising affairs charging them to executive expense accounts as "entertainment," and have given excess income earmarked for party contributions to employees. ${ }^{139} \mathrm{Fi}$ nally, corporations make contributions to trade or business groups or to groups dedicated to particular legislative goals with the understanding that these groups will, in turn, make contributions to the corporation's candidate. ${ }^{140}$

\section{The Shareholder Proposal}

The institution of shareholder voting has traditionally been regarded as one device for ensuring that management administers corporate assets in the interests of those associated with the corporation. Corrupt practices laws also seek to protect these interests by prohibiting certain forms of corporate

136. State v. The Cleveland-Cliffs Iron Co., 169 Ohio St. 42, 157 N.E.2d 331 (1959). But not even this principle of construction could save corporations compensating Mississippi employees for time spent in political primaries. See MIss. Code ANN. $\$ 3172$ (1956).

137. See Bicks \& Friedman, Regulation of Federal Election Finance: $A$ Case of Misguided Morality, 28 N.Y.U.L. REv. 975, 991 (1953); Compare Hearings on S. 636 Before the Subcommittee of the Senate Committee on Rules and Administration, 84th Cong. 1st Sess. 201-03, 209-10 (1955) ; Pettengill, Regulation of Campaign Finance-The Maryland Experience, 19 MD. L. REv. 91, 100-01 (1959).

The Cleveland-Cliffs case is the only reported instance of a post-war prosecution of an endocratic corporation uncovered by research.

138. Cf. Pettengill, supra note 137, at 115.

139. See notes 20-24 supra and accompanying text.

140. Confidential interview with counsel for major industrial corporation. 
involvement in politics. Ideally, shareholder voting procedures would supplement such legislation in two ways. If dissenting shareholders could command a majority of votes, they could provide an internal prohibition on outlawed political activites. If not, shareholder action might still bring the existence of political activity to the attention of the general public and create pressures for enforcement of the act. Shareholder voting might also serve as a valuable control when political activity does occur, whether permitted by law or by failure of enforcement. Here it might serve, at least in part, to legitimize the process of corporate political decision by making it more responsive to stockholder dissatisfaction. Unfortunately, the ideal of shareholder democracy probably cannot be realized in practice. Nevertheless, in the forms of the voting ritual there may exist subtle controls which could be of some value in checking management's political prerogative.

A shareholder could seek to alter company policy by mobilizing support among security holders at an annual meeting for the policy he favors. Most security holders do not attend annual meetings, however, and a stockholder must therefore solicit their proxies. The expense of this solicitation would be minimized if management would voluntarily include the shareholder proposal in its own proxy statement, issued annually at company expense. But management has usually opposed including shareholder proposals on the corporate ballot. ${ }^{141}$ As reasons for its opposition, management has offered the cost of printing the proposal, the liability for libelous statements which may be incurred by the corporation, and the suggestion that many persons who submit proposals are crackpots, publicity seekers, or pleaders for special interests unrelated to those of the corporation. ${ }^{142}$

In order to overcome management opposition, the dissident shareholder can attempt to take advantage of the shareholder proposal provision of the SEC proxy rules. Rule $14 a-8(a)$, adopted by the Securities and Exchange Commission pursuant to $\S 14$ of the Securities and Exchange Act of 1934, provides :

If any security holder entitled to vote at a meeting of security holders of the issuer shall submit to the management of the issuer a reasonable time before the solicitation is made a proposal which is accompanied by notice of his intention to present the proposal for action at the meeting, the management shall set forth the proposal in its proxy statement . . . . 148

If the shareholder's proposal is opposed by management, he can include in

141. Freeman, An Estimate of Practical Consequences of the Stockholder's Proposal Rule, 34 U. DET. L.J. 549, 552 (1957).

142. Hearings on H.R. 1493, H.R. 1821, and H.R. 2019 Before the Subcommittee of the House Committee On Interstate and Foreign Commerce, 78th Cong., 1st Sess. 159 (1943). See id. at 109-11, 119-20, 180, 182, 195; Ledes, A Review of Proper Subject Under the Proxy Rules, 34 U. DET. L.J. 520, 523 (1957).

143. 17 C.F.R. $\$ 240.14 a-8(a)$ (Supp. 1960). 
the management proxy statement his name and address and a statement, not to exceed one hundred words, in support of the proposal. ${ }^{144}$

Under present regulations, not all shareholder proposals fall within this rule. The SEC's first proxy regulations, issued in 1938, implicitly required management to include in its proxy solicitation materials all shareholder proposals it knew would be presented at the annual meeting. ${ }^{145}$ When this requirement was made explicit four years later, ${ }^{146}$ the Commission limited its application to proposals which were proper subjects for stockholder action. "Proper subject," the Commission later explained, ${ }^{147}$ was to be determined by the laws of the corporation's domicile. Under the 1954 revision, a proposal which was a proper subject for shareholder action could nevertheless be omitted if the shareholder's purpose was to promote "general economic, political, racial, religious, social or similar causes" 148 or if the proposal recommended management action concerning the "ordinary business operations" of the company. ${ }^{140}$

Proper Subject. Despite its reference to state law, the "proper subject" test has always proved difficult to apply. Presumably, the test is intended to distinguish between those proposals which management can and cannot rule out of order at an annual meeting, but state law on this subject is virtually nonexistent. ${ }^{150}$ And the subjects which may properly be acted upon by shareholders vary with the type of action contemplated. ${ }^{151}$ Where a proposal merely recommends a course of action to management, the few relevant state cases indicate that it would constitute a "proper subject."152 Where the action purports to bind management, the scope of shareholder initiative is generally limited by state corporation statutes vesting the authority to manage the business of a corporation in its Board of Directors. ${ }^{153}$ Even this

144. Id. at $\$ 240.14 \mathrm{a}-8$ (b).

145. S.E.C. Securities Exchange Act of 1934, Release No. 1823, p. 14, Aug. 11, 1943; see Hearings, supra note 142, at 169-71.

146. S.E.C. Securities Exchange Act of 1934, Release No. 3347, December 18, 1942.

147. S.E.C. Securities Exchange Act of 1934, Release No. 3638, Jan. 3, 1945.

148. 17 C.F.R. $\S 240.14 a-8$ (c) (2) (Supp. 1960). The rule was proposed and adopted separately in 1952. 17 Fed. Reg. 1154 (1952) ; 17 Fed. Reg. 11433 (1952).

149. 17 C.F.R. $\$ 240.142-8$ (c) (5) (Supp. 1960).

150. Ledes, supra note 142, at 524; Note, 57 YALE L.J. 874, 875, 877 (1948); Bayne, Caplin, Emerson \& Latcham, Proxy Regulation And The Rule-Making Process: The 1954 Amendments, 40 VA. L. REv. 387, 401 (1954).

151. Note, 40 VA. L. Rev. 901 (1954).

152. Miller v. Vanderlip, 285 N.Y. 116, 33 N.E.2d 51 (1941); Whitfield v. Kern, 120 N.J. Eq. 115, 184 Atl. 333 (Ch. 1936) (dictum) ; Petit v. Cuneo, 290 Ill. App. 16, 7 N.E.2d 774 (1937); cf. Auer v. Dressel, 306 N.Y. 427, 118 N.E.2d 590 (1954); Dyer v. SEC, 266 F.2d 33, 43 (8th Cir. 1959) (dictum).

One purpose of the proxy rules was to permit shareholders to advise management on matters of policy. See Hearings on H.R. 1493, H.R. 1821 and H.R. 2019 Before the Committec On Interstate and Foreign Commerce, 78th Cong. 1st Sess., 171 (1943).

153. Bayne, Basic Rationale of Proper Subject, 34 U. DET. L.J. 575, 585-86 (1957) (citing statutes); Note, 40 VA. L. Rev. 901, 903 (1954); see, e.g., McQuade v. Stoneham, 263 N.Y. 323,189 N.E. 234 (1934). 
statement is subject to qualification, however. Shareholders have been permitted to compel reporting of the proceedings at annual meetings; they have also succeeded in selecting and appointing permanent auditors to report annually on the affairs of the company, even though the act of selecting a permanent auditor might be thought to be included within the right to manage. ${ }^{154}$ And where shareholders are given the power to amend by-laws by statute or charter, a proposal properly couched in the form of a by-law may become a "proper subject," even though the same proposal cast in the form of a resolution binding upon management might not be..$^{15 \bar{s}}$

The SEC appears to have ruled that a shareholder proposal requiring management to disclose the nature and cost of political activities would not be a "proper subject" under state law. ${ }^{156}$ This ruling seems open to question. Under state law, a shareholder may inspect the books in order to determine if the corporation is being properly managed. ${ }^{157}$ Since political activity is a corporate expense and may have an impact on profits, it would seem that an individual would be permitted to ascertain the costs and objectives of the programs. In the absence of a showing of harm to the corporation arising

154. Emerson, Some Sociological and Legal Aspects of Institutional and Individual Participation Under the SEC's Shareholder Proposal Rule, 34 U. DET. L.J. 52S, 538-39 \& nn.30, 31 (1957) (citing proposals).

155. See Note, 57 Y ALE L.J. 874, 878 (1948). In some states however, only the directors are given power to amend the by-laws. Ibid.

156. Letters From SEC to George B. Driesen, SEC File No. 1-35, March 18, Sept. 30,1960 , on file in Yale Law Library. The shareholder proposal would have amended GE's by-laws to require that:

The corporation shall include in the materials accompanying its annual proxy solicitations a report of the total expenses incurred in support of or in opposition to any political candidate, any legislative proposals (whether or not submitted to popular vote), or any political philosophy or principle. The total so reported shall include expenditures'made directly for advertising, lobbying, propaganda, or political education, or indirectly by contributions made to any group or association, or expended in any other manner. The corporation shall describe in reasonable detail any legislation, candidate, political program or idea for which a sum in excess of $5 \%$ of the total amount reported was expended and shall specify the amount so spent. These reports shall be for the twelve month period corresponding to the corporation's fiscal year.

The company objected that the political affairs program was a matter of management's discretion under state law, and that the proposed reporting would be unduly burdensome to the corporation. See Letter From Gen. Elec. Co. (E. L. Hollis, Gen. Counsel) to S.E.C., Jan. 18, 1960, carbon on file in Yale Law Library. The SEC declined to compel General Electric to include the proposal, accepting the company's reliance upon sub-paragraphs (c) (1), (2) and (5) of its rules, i.e., "proper subject," "political purpose," and "ordinary business operations." The Commission refused to indicate which of the cited sub-sections controlled its disposition of the matter.

157. See, e.g., Guthrie v. Harkness, 199 U.S. 148 (1905). See generally BARER \& Cary, Corporations 737-41 (3d ed. 1958). 
from public disclosure, ${ }^{15 s}$ a shareholder's resolution compelling disclosure should be a proper means of effectuating the right to inspect.

Similarly, adoption of a by-law imposing procedural prerequisites upon management's right to initiate political campaigns would appear to be a proper subject for shareholder action where shareholders retain the power by statute or charter to amend the by-laws. ${ }^{159}$ And state cases sustaining the right of shareholders to recommend a course of action falling within the ambit of management discretion would appear to make shareholder proposals suggesting a particular course of political conduct "proper subjects."160 Although a proper subject, however, such resolutions would probably be barred by the SEC's other limitations on the shareholder proposal rule.

Shareholder Purpose to Promote "Political Causes." SEC Release No. $3638,{ }^{101}$ issued in 1945, represents the Commission's first announced attempt to impose its own standards for determining proper subjects for shareholder action. A shareholder presented for inclusion in management's proxy statement proposals calling for elimination of double taxation of dividend income, revision of antitrust laws, and equal legislative treatment of investors, farmers, and workers. Management sought to omit the proposals on the ground that they were not proper subjects for stockholder action at an annual meeting. The Commission ruled that Rule 14a-7 (now Rule14a-8) did not require management to circulate the proposal. Accepting management's contention that the corporation was "not empowered to engage in political activity," the opinion apparently ruled that, to be a proper subject, a proposal must be directly related to the corporation's business operations, of concern to the shareholders as shareholders in that particular corporation. Accordingly, the opinion concluded that proposals "to obtain the consensus of other stockholders with respect to matters which are of a general political, social or economic nature" were not encompassed by the shareholder proposal rule.

In the 1951 Peck v. Greyhound Corp. decision, ${ }^{162}$ the Commission's reaffirmation of Release No. 3638 was upheld by a United States district court, in one of the few judicial proceedings arising out of the shareholder proposal rules. Peck, the holder of three shares of Greyhound stock, had sought to have a proposal recommending that management consider the advisability of abolishing segregated seating on its buses included in management's proxy materials. When the Commission ruled that the proposal was not a proper subject for shareholder action, relying on its previous release, Peck instituted an action in the district court for a temporary injunction forbidding

158. The power to inspect is usually regarded as a matter of discretion with the court. See, e.g., Guthrie v. Harkness, supra note 157, at 156 (court will "protect the interests of all concerned").

159. Cf. Note, 57 Yale L.J. 874, 878-79 (1948); Slavin, Proper Subject in a Nutshell, 34 U. Det. L.J. 615, 624 (1957).

160. See authorities cited note 152 supra.

161. S.E.C. Securities Exchange Act of 1934, Release No. 3638, Jan. 3, 1945.

162. 97 F. Supp. 679 (S.D.N.Y. 1951). 
management from holding the annual meeting or soliciting proxies unless his proposal was included in the solicitation materials. The court refused to issue an injunction, in part reasoning that the expertise of the Commission in interpreting its own rules should be respected.

The Peck case does not fall within the apparent rationale of the earlier SEC decision; the proposal in Peck was directly related to the carrying on of corporate business. The two decisions might be reconciled, however, if the critical factor in both were the purpose of the shareholder in advancing the proposal, rather than its relation to the corporation's business. In both cases, it appeared that the shareholder was more interested in advancing his particular social and political views than he was in the interest of the corporation. Subsequent to the Peck decision the Commission revised Rule 14a-8, explicitly adopting the "purpose" construction. As amended, the regulations now provide that management may omit any proposal from its proxy statement if "it clearly appears that the proposal is submitted by the security holder ... primarily for the purpose of promoting general economic, political, racial, religious, social or similar causes."183

Shareholder proposals to alter the objectives of corporate political campaigns could probably be omitted from management proxies under this rule. The Commission, weighing the probabilities, is likely to infer that the shareholder is primarily concerned with the political causes he wishes the corporation to foster or oppose. But where disclosure of the costs of a political program is proposed, the shareholder's interest would appear to be primarily related to the program's effect upon earnings and would not be excludable. ${ }^{104}$ Whether the Commission would require circulation of a proposal to abolish or make changes in employee training and released-time programs is unclear. On its fact the proposal does not reveal the shareholder's primary purpose. A shareholder seeking to abolish political training, for example, might be seeking to reduce costs or attract superior personnel, in which case his purpose would presumably be acceptable to the Commission. He might, however, be primarily concerned with conflict of interest problems or the potential for coercion contained in the program, which are essentially socio-political causes.

Arguably, the present business-in-politics movement restricts the applicaability of the "purpose" criterion. The apparent reason underlying the rule is the Commission's belief that it is improper for a shareholder to disturb the economic repose of the corporation by thrusting it into a political arena. ${ }^{105}$ Historically, this rule was founded on the assumption that management is not empowered to engage in political activity. ${ }^{166}$ "Empowered" or not, cor-

163. 17 C.F.R. § 210-14a-8(c) (2) (Supp. 1960), adopted in S.E.C. Securities Exchange Act of 1934, Release 4185, November 5, 1948.

164. But see letters cited note 156 stupra.

165. One commentator has stated that the restriction was designed to preclude abuses of the rule by "persons seeking personal ends to the detriment of the corporation." Ledes, supra note 142 , at 522 .

166. See text at note 161 supra. 
porations are so engaged. Proof of a shareholder's political motive, therefore, does not necessarily prove that he is trying to embroil the corporation in disputes which do not presently concern it. The proposal may be made in the context of an existing political program, and may be intended either to restrict political activity or to direct it to other goals. At the very least, the SEC ought to distinguish between these situations, refusing to apply the rule when a retrenchment from politics is proposed, and possibly when the corporation is already engaged in the activity dealt with by the proposal.

A more appropriate solution would be to abolish the "purpose" criterion altogether. Administration of the rule is made difficult by the fact that Commission decisions are often made ex parte, ${ }^{167}$ forcing the Commission to surmise the shareholder's purpose from the content of his proposal. And even if shareholder purpose were readily ascertainable, relevance of this factor to the propriety of a stockholder resolution is questionable. The only rational basis for the SEC's hostile attitude toward socio-political "causes" would be a presumption that shareholder proposals motivated by political, economic, or social considerations, are either unrelated, or are potentially detrimental, to the ability of the corporation to earn a profit. 168 Realistically, however, the purpose of a shareholder does not determine the impact of his proposal upon profits. Conceivably the adoption of Pecks proposal could, by attracting additional Negro riders, have boosted Greyhound profits. Moreover, the distinction drawn between shareholders with political, economic, and social motives and shareholders having other motives is not found in state law. Under that law the only prerequisite to the exercise of shareholder rights and privileges is stock ownership. ${ }^{169}$

"Ordinary Business Operations." As amended in 1954, Rule 14a-8 further permits management to omit any proposal which "consists of a recommendation or request that management take action with respect to a matter relating to the conduct of the ordinary business operations of the issuer."170 Unfortunately, as was the case with "proper subject for shareholder action" the meaning of "ordinary business operations" in this context is unclear. No Commission releases defining the term have been found.

The Commission has referred to state law as the basis for this rule, ${ }^{171}$ but its definition and application of the rule do not bear out this claim. The rule excludes recommendations relating to ordinary business, while state law seems to draw the line at orders which are binding upon management. ${ }^{172}$ Moreover,

167. See Aranow \& Einhorn, Corporate Proxy Contests: Enforcement of SEC Proxy Rules By the Commission and Private Parties, 31 N.Y.U.L. Rev. 875, 885 (1956).

168. See note 165 supra.

169. See, e.g., N.Y. Stock CoRp. Law $\S 10,45,47$ (1951); Rogers v. American Tobacco Co., 143 N.Y. Misc. 306, 257 N.Y. Supp. 321, aff'd, 233 App. Div. 708, 249 N.Y. Supp. 993 (1931).

170. 17 C.F.R. $\$ 240.14 a-8$ (c) (5) (Supp. 1960).

171. 22 SEC ANN. REP. 103 (1956).

172. See cases cited note 152 supra. 
the few reported decisions incorporating the ordinary-business-operations rule suggest that the Commission is using this as a catch-all concept of omissibility. In one case, for example, this provision was invoked in respect of a shareholder proposal that management not engage in false and misleading advertising in its statements to the public and to other shareholders. ${ }^{173}$ The Commission approved exclusion, apparently on the grounds that the proposal implied that management had engaged in false advertising-a charge not proved before the Commission-and that the actions sought to be prevented by the proposed resolution were already forbidden by state law-in which case the shareholder vote would be of no effect. ${ }^{174}$ This result may, for one or both of these reasons, make good sense. But the reference to "ordinary business operations" seems improper. If management had not, in fact, engaged in false advertising it is difficult to see how false advertising could be said to be an ordinary practice of the corporation. And if management had been falsely advertising, the existence of a state statute on the subject should have been irrelevant for this purpose. ${ }^{175}$ In other cases the Commission has invoked the ordinary-business-operations test to strike down proposals requesting more detailed annual reports, or a rule that shareholder proposals be answered by the president or vice president within ten days. ${ }^{178}$

This test was one of those referred to by the Commission as a basis for allowing management to exclude a proposal for reporting of political objectives and expenses. ${ }^{177}$ Assuming that the "ordinary business operations" test is to be applied in accordance with the common sense meaning of those words, this result seems incorrect. Even if corporate politicking were as "ordinary" as any other business operation, a resolution requiring reporting does not interfere with management's ability to make decisions. At most, it may require changes in accounting procedure. ${ }^{178}$

The decision to adopt or not to adopt a political affairs program would seem to be a major policy decision, outside the "ordinary business operations" exclusion. However, by applying the ordinary operations test in the same manner as it is applied when economic issues are at stake, shareholder proposals relating to specific political objectives would seem to be excluded once the basic decision to institute a program had been made. But the analogy is

173. In the Matter of Union Elec. Co., S.E.C. Holding Company Act, Release No. 13,710, March 21, 1958. This case arose under the Public Utility Holding Company Act of 1935, 49 Stat. 838, 15 U.S.C. $\$ 79 l$ (e) (1958). The Securities Exchange Act proxy regulations apply to solicitations under $\$ 12(\mathrm{e})$. Holding Company Act Release No. 13,710 supra.

174. Ibid. See also In the Matter of Union Elec. Co., S.E.C. Holding Company Act Release No. 13,450, April 17, 1957.

175. Compare Dyer v. SEC, 266 F.2d 33, 46 (8th Cir. 1959).

176. See proposals \#10, \#28, \#30 tabulated in Bayne, supra note 153, at 609-12.

177. See letter cited note 156 supra.

178. Some separate accounting may be necessary even without such a requirement, due to the nondeductibility of certain political expenses for federal tax purposes. See generally Comment, 69 Y ALE L.J. 1017 (1960). 
improper. Management's expertise in business affairs cannot support the same degree of absolute authority when applied to political questions, particularly when issues not intimately affecting company operations are involved.

\section{The Shareholder Vote and the Endocratic Corporation}

The Commission's retreat from the initial broad scope of the shareholder proposal regulation probably reflects disenchantment with its earlier conception of the stockholder function. The original rule was predicated on the assumption that stockholders take an active interest in the affairs of their company and that their concern would be reflected in proposals beneficial to its operation and likely to command support from interested security holders. ${ }^{179}$ In fact, however, few are sufficiently concerned with company affairs to make proposals, support them with convincing arguments if the company seeks to omit them, and appear at the annual meeting to urge their adoption. Dissatisfied shareholders in endocratic corporations sell their securities rather than fight management. ${ }^{180}$

Research has failed to uncover a single shareholder proposal that has been adopted over the opposition of the management of an endocratic corporation. Indeed, stockholders taking advantage of section 14-A-8 have had difficulty mustering more than $10 \%$ of the votes cast at an annual meeting. ${ }^{181}$ Management's ability to defeat any shareholder proposal stems in part from the practice of fiduciaries and institutional holders always to vote their proxies as requested by management, and in part from the tendency of the average shareholder, if he votes at all, to support management as a matter of course. ${ }^{182}$ In addition, a majority of individual owners holding stock in "street" name fail to designate the manner in which they wish proxies to be voted, thereby permitting banks and brokerage houses to vote in favor of incumbents. ${ }^{183}$ These considerations suggest that the shareholder proposal rule does not make the shareholder vote an effective instrument for modifying the policies of endocratic corporations.

But the existence of the rule may nevertheless serve a useful purpose, by attracting attention to existing policies and imposing upon management the necessity for careful consideration of shareholder proposals. By proposing a change in management's policy, a shareholder attracts attention to it. Not only do other shareholders learn about possible objections to existing policy,

179. See 13 SEC Ann. Rep. 41 (1947); 78 Cong. Rec. 7861, 7862, 7864 (1934); Note, 47 Nw. U.L. REv. 718 (1952) ; Bayne, supra note 153, at 576-80.

180. See Livingston, The American Stocknolder 134 (1958). See generally Slavin, supra note 159 , at 616 .

181. See Bayne, Caplin, Emerson \& Latcham, Proxy Regulation and the Rule-Making Process: The 1954 Amendments, 40 VA. L. Rev. 387 (1954).

182. See Berle, The 20tr Century Capitalist Revolutron 30-31 (1954).

183. Freeman, An Estimate of the Practical Consequences of the Stockholder's Proposal Rule, 34 U. DEr. L.J. 549, 553 (1957). 
but, through newspaper accounts of stockholder meetings, the dispute may also be brought to the attention of a wider public. ${ }^{184}$ Publicity is distasteful to most executives, who fear criticism even by those unable to translate their objections into remedial action. ${ }^{185}$ This sensitivity may stem in part from a fear of public opinion which, if aroused, may lead to legislative restraints. ${ }^{180}$ The fear of public opinion may be a particularly strong force when corporate political activities are involved, because political controversies would seem to interest a wider public than mundane business struggles. In furtherance of its desire to forestall criticism, management will tend to avoid actions which might induce shareholders to suggest policy changes.

A second function of the shareholder proposal is to force management carefully to consider a suggested change and to review its policy in the light of the implied criticism. ${ }^{187}$ The shareholder proposal is similar to, but more effective than, a letter from a customer, supplier, employee, or stockholder to management. It is highly unlikely that the contents of a letter will be brought to the attention of many top executives, but a proposal inevitably comes to the attention of a large number of responsible persons. If the proposal is included in the proxy material pursuant to the rule, most corporate officers will see it. If the corporation intends to exclude the proposal, corporate counsel will have to examine it and present objections to the SEC. And at least one member of management will have to be prepared to debate the proposal with the shareholder at the annual meeting. Thus the shareholder proposal will serve to communicate some opposing views to management and, at least to this extent, will make the program adopted more representative of the corporate constituency.

\section{The Shareholder Derivative Suit}

To the extent that shareholder derivative suits can successfully be used to challenge management's political activity, they may serve to protect several

184. Shareholder meetings are sometimes reported in newspapers of general circulation. See, e.g., N.Y. Times, April 21, 1960, p. 41, col. 4 (A.T.\&T.) ; id., April 27, 1960, p. 49, col. 5 (W.T. Grant) ; id., April 28, 1960, p. 219, col. 6 (General Electric).

The "wider public" may include institutional investors who can exercise control over management policy if they desire to do so. See Berle, Power Without Property 48-50 (1959) ; Livingston, The American Stockholder 163 (1958).

185. See BerLe, op. cit. supra note 184, at 109-10. See generally BerLe, The 20TH Century Capitalist Revolution 74-77 (1954). See also Livingston, op. cit. supra note 184 , at 197, 204 (disclosure forces management to observe higher ethical standards).

The president of the Prudential Insurance Co. resigned in the face of stockholder criticism of legally acceptable transactions between him and the company despite the probability that he had not damaged the corporation. N.Y. Times, Sept. 14, 1960, p. 61, col. 2; id., December 24, 1960, p. 49, col. 5.

186. See Berle, The 20tr Century Capitalist Revolution 54-65, 113-15 (1954). The dormant power of institutional shareowners to replace incumbents may be another source of management restraint. LIVINGSTON, op. cit. supra note 184, at 163. But see BERLE, op. cit. supra at 36.

187. Freeman, supra note 183 , at $554-55$. 
interests. At one level, the derivative suit protects the economic interests of shareholders from depredation by corporate officials using the company's assets to propagate their own ideas. The threat of a derivative suit may also compel management to consider shareholder reaction to its selection of political goals, as well as the community reaction which might be reflected in judicial response. Finally, the shareholder litigant, whatever his own motives, may serve as a tool of state policy protecting the political process. The categories of proper and improper management action-the causes of action for shareholder-may be moulded by considerations of public policy reaching beyond the immediate confines of the corporation. Public goals will also be served by the probability that plaintiffs will not sue unless political spending reaches noticeable proportions, a consideration which may induce management to keep spending to a minimum and thus reduce the impact of corporate wealth on politics. Both substantive and procedural obstacles, however, raise some doubt about the utility of the shareholder suit in this area.

The derivative suit is an action instituted by a shareholder on behalf of the corporation to assert a claim which the corporation has against insiders or third parties. Unless a majority of the directors are themselves defendants in the suit, a request that the Board institute legal proceedings to have the claim asserted is usually a prerequisite. ${ }^{188}$ In many instances, the plaintiff-shareholder is further required to demonstrate that he has attempted to initiate stockholder action. ${ }^{189}$ Although damages are payable to the corporation, the plaintiff-stockholder is entitled, if successful, to charge his counsel fees and expenses against the recovery. ${ }^{190}$ Where relief other than damages is sought, the shareholder may nevertheless be reimbursed by the corporation if it has received a tangible benefit. ${ }^{191}$

A derivative suit attacking a corporation's political program might be based on the theory that these programs, not being authorized by charter, or statute, are ultra vires. The channeling of corporate assets into politics would constitute waste for which directors and officers would have to account to the corporation. ${ }^{192}$

Traditionally, the law viewed corporations as legal entities authorized to exercise those powers granted by the state in order to achieve charter purposes. ${ }^{193}$ Powers may be granted expressly by charter or statute or by implication when found necessary or convenient to achieve stated purposes. If a corporation acts beyond its powers, it is said to be acting ultra vires. The classical example of ultra vires would be the operation of a steamboat by a cor-

188. Lattin, Corporations 352 (1959).

189. Ibid.

190. Id. at 381.

191. See, c.g., Kaufman v. Shoenberg, 33 Del. Ch. 282, 92 A.2d 295 (Ch. 1952); Dottenheim v. Emerson Elec. Mfg. Co., 77 F. Supp. 306 (E.D.N.Y. 1948).

192. See Ham, Ultra Vires Contracts Under Modern Corporate Legislation, $46 \mathrm{KY}$. L.J. 215, 231-32 (1958) (citing statutes).

193. See generally Baker \& Cary, Corporations \$\$ 58-73 (3d ed. 1958). 
poration chartered to run a railroad. In recent years statutes have considerably broadened corporate powers ${ }^{194}$ and courts have tended to permit corporations to exercise virtually any power not expressly prohibited so long as they find that the acts done "benefitted" the corporation. ${ }^{195}$ If corporate benefit alone were the standard, political expenditures would easily avoid charges of ultra vires. The benefit of campaigns relating to legislation having an immediate effect on industry profits seems obvious. Political activity of a more general nature, such as the propagation of political ideals friendly to corporate enterprise, employee political training, and released-time programs, might also qualify under the more attenuated concept of "benefit to the corporation" used to sustain corporate charitable contributions. A leading case in the charitable contributions area reasoned that a corporation would benefit from donations to a community church, because a better community would draw better workers. ${ }^{196}$

The few cases mentioning the propriety of political expenditures, however, all concluded that such action would be ultra vires. ${ }^{197}$ In at least one case, management explicitly sought to justify the political activity, campaign contributions, on grounds of its benefit to the corporation. ${ }^{198}$ In another, the court considered political and charitable contributions separately in passing upon expenses to determine a public utility's rate schedule; it concluded that while charitable donations were probably proper corporate expenses, political expenditures were "personal" and not allowable. ${ }^{109}$ The wording of judicial statements suggests that they may be based on a myopic view of political

194. For example, many statutes now authorize corporations to make charitable contributions. Some have no explicit requirement of corporate benefit. See, e.g., CAI. CoRp. Code Ann. § 802(g); Conn. Gen. Star. Ann. \$ 33-16(10) (1958); Ky. Rev. Stat. $\S 271.125$ (13) (1955). Others explicitly retain the corporate benefit rule, however, see, c.g., N.Y. Gen. Corp. Laws $\$ 34$; OrLa. Stat. Ans. tit. 18:1-.19(11), and it may be argued that the benefit requirement survives the statutes. See Memorial Hospital Ass'n v. Pacific Grape Prod. Co., 45 Cal. 2d 634, 290 P.2d 481 (1955) ; Union Pac. R.R. v. Trustees, Inc., 8 Utah 2d 101, 329 P.2d 398 (1954) ; Moore v. Keystone Macaroni Mfg. Co., 370 Pa. 172, 87 A.2d 295 (1952). Some states key their charitable contributions statutes to the Internal Revenue Code. See, e.g., Ind. ANN. STAт. \& 25-211(b) (1960). Corporations in these states could not rely upon these statutes to validate political activities. See Commarano v. United States, 358 U.S. 498 (1959).

195. See BAKER \& CARY, op. cit. supra note 193, at 358, 366; A.P. Smith Mfg. Co. v. Barlow, 13 N.J. 145, 98 A.2d 581, appeal dismissed, 346 U.S. 861 (1953) ; Hutton v. West Cork Ry. Co., [1883] 23 L.R. (Ch.) 654, 673.

196. Steinway v. Steinway \& Sons, 17 Misc. 43, 40 N.Y. Supp. 718 (Sup. Ct. 1896). See generally Note, 8 Rutgers L. Rev. 527 (1954).

197. Mobile Gas Co. v. Patterson, 293 Fed. 208, 226 (M.D. Ala. 1923) (campaign contributions are personal expenditures of officers for rate-making purposes); McConnell v. Combination Min. \& Mill. Co., 31 Mont. 563, 79 Pac. 248 (1905) (expenses incurred in lobbying for passage of a bill charged to directors as beyond corporate purposes) ; People ex rel. Perkins v. Moss, 187 N.Y. 410, 439, 80 N.E. 383, $386-89$ (1907) (dictum) (larceny prosecution for contributing corporate funds to political party).

198. People ex rel. Perkins v. Moss, 187 N.Y. 410, 439, 80 N.E. 383, 385 (1907).

199. Mobile Gas Co. v. Patterson, 293 Fed. 208, 226 (M.D. Ala. 1923). 
activity as an end in itself, and, as such, ultra vires for not being listed as one of the corporate purposes in the charter. ${ }^{200}$ More likely, however, the courts were saying that certain acts, regardless of their probable effect, were simply foreign to the conceptual image of what a corporation was and what it could do. Allied with this notion in one of the cases is the suggestion that corporate political involvement was against public policy. ${ }^{201}$ The cases in question were decided before 1925, during and shortly after the era in which the corruption of contemporary corporate politicking was exposed and assaulted by a wave of corrupt practices legislation. The ultra vires notion may have been, at least in part, the product of this reform movement.

The present authority of these early cases is questionable. None gave extended consideration to the problem. Furthermore, the conceptual view of the corporation as nonpolitical, by its nature, seems irrelevant today. And it no longer seems necessary to equate corporate politics with bribery. This does not mean that public policy might not be offended in other ways; the unrepresentative nature of political decision making in the endocratic corporation still constitutes an encroachment on fundamental values. But even this important shortcoming must be balanced against the corporation's problem of competing in a business world often dominated by governmental regulation. The use of the ultra vires doctrine may further be hampered by the general disfavor with which the doctrine has been viewed in recent years. Commentators have insisted that engrafting public policy notions on the ultra vires doctrine does violence to that concept. ${ }^{202}$ Courts may hesitate to employ the doctrine despite the fact that criticism has rested primarily on the harm done to third parties dealing in good faith with the corporation, whose contracts can be voided by the finding of ultra vires ${ }^{203}$ - a problem not immediately apparent when shareholders sue directors for waste, or to enjoin a political program.

Although it is probably impossible to speak of political activity as per se ultra vires, ${ }^{204}$ the challenge may be effective against campaigns which are of

200. E.g., McConnell v. Combination Min. \& Mill. Co., 31 Mont. 563, 571, 79 Pac. 248, 251 (1905) ("a purpose wholly foreign to those of a mining corporation").

201. People ex rel. Perkins v. Moss, 187 N.Y. 410, 80 N.E. 383, 388 (1907) (dictum) (concurring opinion). Occasionally courts will invoke the concept of ultra vires to invalidate a transaction which, although not specifically prohibited, seems offensive on public policy grounds. See, e.g., Texas \& Pac. Ry. v. Pottoroff, 291 U.S. 245 (1934) (Brandeis, J.) ; Awotin v. Atlas Exchange Nat'l Bank, 275 Ill. App. 530 (1934), aff'd, 295 U.S. 209 (1935) ; McWilliams v. Central States Life Ins. Co., 137 S.W.2d 641, 646 (Mo. Ct. App. 1940). See also National Inv. Co. v. National Sav., Loan \& Bldg. Ass'n, 49 Minn. 517, 52 N.W. 138 (1892) (prohibited transaction beyond "powers").

202. E.g., Ballantine, Corporations $\$ 92$ (1946).

203. See Ballantine, Proposed Revision of the Ultra Vires Doctrine, 12 CoRNelz L.Q. 453 (1927).

204. It might be argued that some of the explicit exceptions to state corrupt practices laws dealing with corporations constitute implicit legislative recognition that some forms of political activity are proper corporate activities. See, e.g., Mass. ANn. Laws ch. 55, $\S 7$ (1953) (excepting political activity affecting corporate property); WIs. STar. ANN. 
remote benefit to the corporation. The extension of the benefit concept in the charitable contributions cases appears to have been based upon another public policy concept, the view that corporations as holders of large wealth must be allowed to contribute if charities are to function effectively in the age of declining private fortunes. 205 This rationale of necessity does not apply to political activities; the corporation's views and training activities, while often valuable, do not seem essential to the political process. Apparently in accord with this view, one state attorney general has ruled that statutes authorizing charitable gifts do not authorize political support by savings and loan associations on ballot propositions "unless the proposition is found to be 'necessary and convenient' to the advancement of the 'purposes' for which these associations were formed."206 The charitable contribution cases would support nonprofit making political expenditures only if they are read to hold that any activity which is intended to promote the national welfare is intra vires.

Other causes of action might be available. The New York Court of Appeals in Abrams $v$. Allen ${ }^{207}$ has held that an allegation charging use of corporate assets to promote an official's personal view states a cause of action for waste, mismanagement, lack of due care, or conversion-"depending on circumstances." Separation of personal views from those propounded for the benefit of the corporation would, of course, be difficult. If the magnitude of the expense incurred were substantial, however, and the relationship to corporate profits remote, the plaintiff might argue that this amount of evidence establishes a prima facie case of wasting corporate assets which shifts the burden to defendants to prove good faith. ${ }^{208}$

$\S 12.56$ (b) (Supp. 1960) (excepting dissemination through company organs of views about effect of measures and candidates on corporation). See Smith v. Higinbotham, 187 Md. 115, 48 A.2d 754 (1946); La Belle v. Hennepin County Bar Ass'n, 206 Minn. 290, 288 N.W. 788 (1939). Quaere the reverse inference that activity prohibited is ultra vires.

205. See, e.g., A. P. Smith Mfg. Co. v. Barlow, 13 N.J. 145, 149-54, 98 A.2d 581, 584, 585-86, appeal dismissed, 346 U.S. 861 (1953) ; accord, Union Pac. R.R. v. Trustees, Inc., 8 Utah 2d 101, 105, 329 P.2d 398, 400 (1958); Note, 22 Geo. Wash. L. Rev. 710 (1954).

206. Opinion Letter to the Savings and Loan Commissioner, California Attorney General, October 14,1960 , p. 2 (alternative ground). The political issue involved a proposed issue of state water bonds. The Attorney General argued that the intent of the legislature in passing the statute was to broaden the power of corporations to enable them to make gifts to charitable instrumentalities. But the term "public welfare," used in these statutes, does not extend to political causes, the attorney general ruled. Ibid. Compare Clark, The Limitation On Political Activities: $A$ Discordant Note in the Law of Charities, $46 \mathrm{VA}$. I. REv. 439 (1960) (political infuence and activity essential to realize goals of many charities). The Attorney General relied, in part, upon the distinction drawn in the carly cases between philanthropies benefiting the corporation, permitted at common law, and political contributions, which were forbidden.

207. 297 N.Y. 52, 74 N.E.2d 305 (1947). On remand plaintiff was unable to prove that defendant's actions were motivated solely by an intent to defeat unionization. Abrams v. Allen, 113 N.Y.S.2d 181 (Sup. Ct. 1952).

208. The argument would be based on analogy to the rule in some jurisdictions that directors have the burden of proving that their contracts with the corporation were made in good faith and were inherently fair. Pepper v. Litton, 308 U.S. 295, 306 (1939); Geddes v. Anaconda Copper Mining Co., 254 U.S. 590, 599 (1921). 
The court in Abrams $v$. Allen also ruled that use of corporate assets to do an unlawful act would constitute a cause of action. ${ }^{200}$ This raises the issue of the inter-relationship between corrupt practices acts and the shareholder suit. Whatever the scope of the Abrams holding, ${ }^{210}$ it seems peculiarly applicable to violations of the corrupt practices acts by corporate officers. The shareholder here would not merely be suing to prevent some abstract "public wrong." Although corrupt practices legislation is criminal, it usually had as one of its purposes to prevent the use of corporate assets to support political positions some stockholders might oppose. ${ }^{211}$ The action might further be supported by analogy to the private actions which have been allowed under the criminal sections of federal securities legislation. ${ }^{212}$

The uncertain scope of any of these causes of action makes forecasting the probability of success in a stockholder derivative action difficult and thereby discourages such litigation. But even if the political activity in issue were clearly actionable, "death knell" statutes in force in most commercial jurisdictions have virtually precluded use of derivative suits. Section $61(\mathrm{~b})$ of the New York Corporation Law is typical. It requires a plaintiff who owns less than five per cent of the corporation's outstanding stock, or less than a stated market value, to post security for the legal expenses incurred by the corporation and the individual defendants. ${ }^{213}$ This financial requirement is usually more than plaintiff can bear. ${ }^{214}$

Under some circumstances, it might be possible to bypass the discouraging effect of a death knell statute. Plaintiff could, for example, shop for a forum which does not have such a statute. ${ }^{215}$ The substantive issue in the derivative action, whether political activities are actionable, must be determined by the

209. 297 N.Y. at 56,74 N.E.2d at 306.

210. For discussion of the possible ramifications of this doctrine, see Note, 57 Yale L.J. 489 (1948).

211. See note 109 supra and accompanying text. Where the legislative history of a criminal statute demonstrates that its interest was to protect a particular class while achieving a public benefit, courts will afford a civil remedy to members of the class. Remar v. Clayton Sec. Corp., 81 F. Supp. 1014 (D. Mass. 1949) (Wyzanski, J.). And where, as here, see text at notes 137-40 supra, the public remedy has proven inadequate, courts following common law principles may provide civil remedies. See Tunstall v. Brotherhood of Locomotive Firemen, 323 U.S. 210 (1944) (injunction). But not all criminal statutes apparently protecting individuals give rise to civil remedies. See, e.g., Bell v. Faulkiner, 75 S.W.2d 612 (Mo. Ct. App. 1934) (statute forbidding interference with employees' right to vote).

212. See Loss, The SEC Proxy Rules in the Coutts, 73 HaRv. L. Rev. 1041 (1960); Note, 59 Y ALE L.J. 1120, 1133-35 (1950); 37 A.L.R.2d 649 (1954) (Annot.).

213. N.Y. Gen. CoRp. LAw § 61(b); Note, 52 Colum. L. Rev. 267 (1952); Note, 1956 WIs. L. REv. 322.

214. See Hornstein, New Aspects of Stockholders' Derivative Stits, 47 Colum. L. Rev. 1, 5 (1947); Hornstein, The Death Knell of Stockholders' Derivative Suits in New York, 32 CALIF. L. REv. 123 (1944).

215. See Berkwitz v. Humphrey, 130 F. Supp. 142 (N.D. Ohio 1955). 
law of the corporation's domicile. ${ }^{216}$ But the security-for-expenses aspect of the derivative action is procedural for conflicts of law purposes, and is therefore governed by the law of the forum. ${ }^{217}$ In the alternative, plaintiff might bring a personal action, to which the security-for-expenses statutes do not apply. ${ }^{218}$ In such an action, however, his remedy is restricted to an injunction against future political activities. ${ }^{219}$ Damages will not be awarded unless plaintiff can establish a relationship to defendant directors other than that based on share ownership. ${ }^{220}$

\section{The Constitutional Question}

Two of the controls this Comment has considered, shareholder derivative suits and corrupt practices acts, raise questions concerning the constitutional protection of freedom of speech. Corrupt practices acts, construed to prevent a corporation from expressing its views to the public, and decrees issued in shareholder suits would limit the right to speak freely-if that right is available to corporations.

Initially, corporations were held not to be entitled to exercise the liberties of speech and press accorded to natural persons. ${ }^{221}$ Despite reliance on this doctrine by some lower courts in recent years, ${ }^{222}$ the distinction between natural and artificial persons appears to have been weakened by later decisions -not all explicitly considering the corporate character of the claimant. In-

216. Restatement, Conflict of Laws $\$ \$ 187-89$ (1934); Cheatham, Gooprich, Griswold \& ReEse, Cases on Conflict of Laws 988 (1957).

217. Berkwitz v. Humphrey, 130 F. Supp. 142 (N.D. Ohio 1955). See Cohen v. Beneficial Indus. Loan Corp., 337 U.S. 541 (1949).

218. The state statutes apply only to plaintiffs suing in the right of the corporation. See, e.g., N.Y. Gen. CoRp. LAw $\$ 61$ (b); Wis. Stat. ANn. \$ 180-405(4) (1957); N.J. Stat. Ans. 14:3-15 (Supp. 1960).

For the distinction between derivative and personal actions, see LATTIN, CoRporations 346-48 (1959).

219. See id. at 348; Glenn, The Stockholder's Suit-Corporate and Individual Grievances, 33 YaLE L.J. 580, 584 (1924); Note, 40 CaLIF. L. REv. 127, 129 (1952); General Inv. Co. v. Lake Shore \& M.S. Ry., 250 Fed. 160 (6th Cir. 1918) (dictum), aff'd, 260 U.S. 261 (1922).

220. Dickinson v. Consolidated Traction Co., 114 Fed. 322 (C.C.D.N.J. 1902) (dictum) ; Elster v. American Airlines, Inc., 34 Del. Ch. 94, 100 A.2d 219 (1953). The shareholder may be able to recover his expenses, however. See Latrin, Corporations 381 (1959); Holthusen v. Edward G. Budd Mfg. Co., 55 F. Supp. 945 (E.D. Pa. 1944).

221. Hague v. Committee for Indus. Organization, 307 U.S. 496, 514, 527 (1939); Comment, 66 Yale L.J. 545, 547-50 (1957); accord, People v. Gansley, 191 Mich. 357, 376, 158 N.W. 195, 201 (1916); see Northern Nat'1 Life Ins. Co. v. Riggs, 203 U.S. 243 (1906); Western Turf Ass'n v. Greenberg, 204 U.S. 359 (1907) ; Pierce v. Society of Sisters, 268 U.S. 510, 535 (1925).

222. Hallmark Productions v. Moseley, 190 F.2d 904, 909 (8th Cir. 1951) (dictum); Joint Anti-Facist Refugee Committee v. Clark, 177 F.2d 79, 83 (D.C. Cir. 1949), rev'd on other grounds, 341 U.S. 123 (1951). 
corporated motion picture companies ${ }^{223}$ and newspapers ${ }^{224}$ have successfully invoked constitutional freedoms of speech and press in resisting state tax and censorship statutes. In only one of these cases, Grosjean v. American Press Co., was the applicability of the amendment to a corporation challenged, and there the court summarily disposed of the issue in the corporation's favor. ${ }^{225} \mathrm{~A} \mathrm{sec}-$ ond line of cases in which the issue arose involved restrictions under the National Labor Relations Act upon allegedly coercive anti-union speech by corporate employers. In these cases, lower courts have assumed that the first amendment limited the restraints the NLRB might impose; here again the corporate nature of the employer was not considered. ${ }^{226}$ The Supreme Court was able to dispose of these cases without invoking the corporate employer's freedom of speech. ${ }^{227}$ But in NAACP v. Alabanta, ${ }^{228}$ the Court was presented with a New York membership corporation's claim to first amendment rights, and refused to decide the case on that basis. Rather, it sustained the NAACP's refusal to produce membership lists on the ground that it was asserting the rights of its members-something it was entitled to do because "it and its members are in every practical sense identical."220 This case suggests that the first amendment rights of corporations are derivative and not available to the legal entity as such. A final comment on this development is an unexplained distinction implied by a dictum of Mr. Justice Reed:

If $\S 313$ [of the Federal Corrupt Practices Act] were construed to prohibit publication, by corporations ... in the regular course of conducting their affairs, of periodicals advising their . . . stockholders or customers of danger or advantage to their interests from the adoption of measures, or the election to office of men espousing such measures, the gravest doubt would arise in our minds as to its constitutionality. ${ }^{230}$

Even though these cases indicate that the right of free speech may be available to some corporate defendants, the paucity of authority makes accurate determination of that right difficult. The main problem, assuming the existence

223. Superior Films, Inc. v. Dep't of Education, 346 U.S. 587 (1954) (film censorship) ; Joseph Burstyn, Inc. v. Wilson, 343 U.S. 495 (1952); Adams Newark Theatre Co. v. City of Newark, 39 N.J. Super. 111, 120 A.2d 496 (Super. Ct. Law Div. 1956).

224. Grosjean v. American Press Co., 297 U.S. 233 (1936). See also Pennekamp v. Florida, 328 U.S. 331 (1946) (newspaper corporation's comment on trial not punishảble as contempt) ; Bridges v. California, 314 U.S. 252 (1941) (semble).

225. 297 U.S. at 244.

226. NLRB v. Montgomery Ward \& Co., 157 F.2d 486, 498-99 (8th Cir. 1946) ; NLRB v. Ford Motor Co., 114 F.2d 905 (6th Cir. 1940), cert. denied, 312 U.S. 689 (1941).

227. See NLRB v. Virginia Elec. \& Power Co., 314 U.S. 469, 477 (1941). The case was cited as granting first amendment protection in Thomas v. Collins, 323.U.S. 516, 537 (1945) (Rutledge, J.).

228. 357 U.S. 449 (1958).

229. 357 U.S. at 459.

230. United States v. CIO, 335 U.S. 106, 121 (1948) (dictum). See also Cammarano v. United States, 358 U.S. 498, 514-15 (1959) (Douglas, J., concurring) (profit corporation has right of free speech). 
of the right, is to identify when it is that "the corporation" is speaking. If the corporation's right is based upon the right of its members to use the corporate medium to express their views, an inquiry into the relationship between members and the corporate speech might be in order. This inquiry might take the form suggested in the $N A A C P$ case, an inquiry into the "identity" of members and organization. The statement of Mr. Justice Reed might give content to this formula, suggesting that protected speech is communication affecting the "interests" of shareholders or customers-presumably their interest in the continued prosperity of the corporation. ${ }^{231}$ Unfortunately, an "interest" criterion alone has little meaning, especially in the context of political activity. Narrowly construed, it would protect communication of management's views concerning the impact of any proposed or actual govermental action which related to any present activity of the corporation's employees or officers. On the other hand, if expanded notions of the ambit of corporate responsibility become accepted as in the law governing corporate contributions to charity, speech concerning any question of public policy could be protected from state and federal regulation.

Another approach to the problem of defining "corporate" speech might begin by asking whether the officer speaking has been "authorized" to speak by the corporation. The corporation's right of free speech is of significance in the political context because it permits appropriation of company assets for the purpose of propagating ideas. In ordinary corporate transactions, the authority of an officer to use corporate assets is determined by state law. ${ }^{232}$ While a federal right is being defined in this case, state law must to some degree be the referent of the corporate action which the Supreme Court may declare protected.

The concept of authority involves two determinations. First, if state law forbids corporations to speak on political matters, an officer's political speech would not be authorized. This element of the authority concept cannot be relevant, for a constitutional right to speak, by definition, would preclude states from imposing this kind of limitation. The second element of authority is the grant of powers and stated purposes contained in the charter. ${ }^{233}$ The

231. The statement by Mr. Justice Reed was concerned only with communications to shareholders and customers. And the labor cases have dealt only with employees. One state has apparently adopted the view that communications to persons outside these groups are not protected. See WIs. Stat. ANN. $\$ 12.56$ (b) (1957). But such a limitation makes little sense. It is inconsistent with one purpose of first amendment protection-to maintain a "market place of ideas." See Abrams v. United States, 250 U.S. 616, 630 (1919) (Holmes, J., dissenting). See also Richardson, Freedom of Expression and the Function of Conts, 65 Harv. I. REv. 1, 3-4 (1951). To maximize that value, the corporation "should be able to speak to an unrestricted audience. Perhaps Mr. Justice Douglas thought that the corporation itself had no right of free speech, but that the right of shareholders and customers to protect their interests by exercising ordinary political rights demands that some channel of communication between them and management be kept open.

232. See St. Louis, V. \& T.H.R.R. v. Terre Haute \& I.R.R., 145 U.S. 393 (1892). See also Hopkins Fed. Sav. \& Loan Ass'n v. Cleary, 296 U.S. 315 (1935).

233. See Baker \& Cary, Corporations 359 \& n.6 (3d ed. 1958). 
charter authorization gives some indication of the interests which identify the organization and its members. It may give notice to stockholders of the corporation's purposes, and places some power in their hands to change or at least to resist changes in that purpose. This meaning of authorization seems relevant to the constitutional question. It focuses on the nexus between the speech and the individuals on whose behalf protection of the organization's right seems most justifiable.

The second element of authorization is precisely what the ultra vires derivative suit seeks to determine. If the use of corporate assets for political "speaking" is found ultra vires, its prohibition does not trangress the corporation's right to free speech. The activity is not speech of or for the corporation. A similar conclusion would follow if the speech was prohibited under the Abrams v. Allen theory-that it represented a personal view and not the view of the corporation. ${ }^{234}$ The cause of action rests on the appropriation of corporate assets for personal use; the fact that speech was the motive seems irrelevant.

The significance of corrupt practices acts in defining corporate free speech is unclear. On the one hand, the stated purpose of protecting shareholders from having their assets used for purposes contrary to their own beliefs ${ }^{235}$ sounds like a generalized conclusion that shareholders do not authorize use of their assets for electioneering. Arguably, therefore, all expenditures proscribed by the act do not come within the protection of corporate speech, because they are noncorporate. But the generalized application of this presumed lack of authorization would seem arbitrary in many cases, particularly where the corporation is a nonprofit organization expressly devoted to political action. State courts have avoided this issue in most cases by deciding that the act did not apply to such organizations, reasoning that corrupt practices legislation was intended to reach business corporations whose large accumulations of wealth were a threat to the political process. ${ }^{236}$ While this rationale avoids one problem, it raises another. It reveals that the major purpose of these acts has nothing to do with shareholder authorization. Rather, the legislation represents a statement of policy that corporate political participation is harmful to the public. This policy must be regarded as a restraint on corporate speech, and must, therefore, be judged under constitutional standards pertaining to free speech. The same conclusion would apply with even greater certainty in the case of the Federal Corrupt Practices Act, for the purpose of defining shareholder authorization would seem foreclosed to a federal leglature.

If, under either approach, the activity challenged can be categorized as corporate speech, all governmental regulation is not necessarily precluded. First

234. 297 N.Y. 52, 74 N.E.2d 305 (1947).

235. See note 109 supra.

236. Smith v. Higinbotham, 187 Md. 115, 48 A.2d 754 (1946); La Belle v. Hennepin County Bar Ass'n, 206 Minn. 290, 288 N.W. 788 (1939); State v. Joe Must Go Club of Wisconsin, Inc., 270 Wis. 108, 70 N.W.2d 681 (1955). 
amendment protections are not absolute; where a legitimate state interest is threatened, reasonable regulation is permitted. ${ }^{237}$ Arguably, the state has an interest in maintaining a "market place of ideas." 238 The danger is that corporate managers, given enormous resources at their command, could effectively flood the market place and thus stifle any genuine attempt at effective debate. $^{239}$ This theory might sustain imposition of dollar limitations on the amount of corporate assets-cash, services of employees, and equipmentwhich management may devote to the dissemination of its ideas. ${ }^{240}$

\section{Concluston}

The novelty of corporate political affairs programs argues against the application of more stringent legal controls before there is an opportunity to examine their actual effect upon shareholders, managerial personnel, hourly rated employees, and the public. Possibly, corporate managers will set up internal mechanisms to protect employees from overzealous superiors. It may also be that the volume of resources committed to these programs will not be great enough to warrant concern for shareholder interests, and corporate persuasion programs may simply add another competing voice to the clamor for public political allegiance. But so long as corporate managements do not account separately for the costs of their political activities and do not disclose their efforts in detail ${ }^{241}$ neither legislators, courts, nor shareholders can be

237. Times Film Corporation v. Chicago, 29 U.S.L. WeEk 4120 (Sup. Ct. Jan. 23, 1961) ; Kovacs v. Cooper, 336 U.S. 77 (1949) ; Patterson v. Colorado, 205 U.S. 454, 463 (1907) ; Robertson v. Baldwin, 165 U.S. 275, 281 (1897).

238. Abrams v. United States, 250 U.S. 616, 630 (1919) (Holmes, J., dissenting); see Stromberg v. California, 283 U.S. 359, 369 (1931); De Jonge v. Oregon, 299 U.S. 353,365 (1937).

239. Cf. United States v. Painters' Local, 79 F. Supp. 516, 521-23 (D. Conn. 1948), reversed on other grounds, 172 F.2d 854 (2d Cir. 1949); United States v. United States Brewers' Ass'n, 239 Fed. 163, 168 (W.D. Pa. 1916) ; Note, 27 FordHan L. Rev. 599, 609 (1959). Compare Meirlejohn, Freedon of Speech 75 (1960). For an example of corporate managers translating economic into political power, see Salisbury, N.Y. Times, April 13,1960 , p. 33, cols. 3-4.

Congress recognized that the ability to communicate one's ideas without cost to oneself could create an unfair political advantage. Conflict of INTEREST 54-55 (franking privilege denied "dollar-a-year" men).

If corporate persuasion campaigns were too successful, they could diminish the possibility of securing legislation adverse to the interests of the company or the industry, thereby weakening the controls which impel corporate managers to act in the public interest. Cf. Brewster, The Corporation and Economic Federalism, in Mason, The Corporation IN MODERN SOCTETY 72, 74-75 (1959). In addition to giving corporate managers' opinions an overly effective impact on the elecforáte, political use of corporate funds could enable officers to frame the issues for public debate. Cf. Blatsdell, American Democracy Uniner PRESSURE 4 (1957).

240. Poulos v. New Hampshire, 345 U.S. 395, 403 (1953) ; Kovacs v. Cooper, 336 U.S. 77, 86 (1949) (dictum) ; Smith v. Ervin, 64 So. $2 d 166$ (Sup. Ct. Fla. 1953) ; MerkeLJOHN, op. cit. supra note 239, at 24-25 (1960).

241. None of the companies polled had set up separate accounting for political expenses. QUeSTIONNAIRE. 
expected to react realistically ${ }^{242}$ to occasional revelations of political activity or to determine what, if any, additional legal controls are needed to supplement the present means of supervising corporate political activities.

Disclosure' might be compelled by the Securities Exchange Commission under $\$ 13$ (a) of the Securities Exchange Act of $1934{ }^{243}$ which requires every issuer of a security registered on a national securities exchange and every issuer required to file a registration statement to file such reports as the Commission may prescribe as necessary or appropriate for the protection of investors. The Commission might require annual reports filed in compliance with regulations now in effect, ${ }^{244}$ to include a statement of the costs of political training programs, the amounts paid to employees under released time programs, and the amounts spent directly or indirectly (through contributions to business leagues, trade associations, and "educational" organizations), to influence the political views of shareholders, customers, employees, and the public. In addition, the Commission could require a company to identify the objective of any single campaign which accounted for more than, say, $5 \%$ of the total amount spent. Since annual reports filed with the Commission are not generally available to stockholders, and other interested parties, the figures reported to the SEC could be summarized in proxy statements accompanying solicitation of shareholder votes for use at the annual meeting. ${ }^{245} \mathrm{~A}$ regulation of this kind might meet the statutory requirement that it be necessary or appropriate for investors, on the theory that political programs may be a factor in financial success; investors should be supplied with some information to enable them to appraise the probable impact of the program upon future earnings and current costs. Disclosure would also enable shareholders to take appropriate action if an unreasonable amount of corporate funds were being devoted to political purposes. ${ }^{246}$ The regulation would also make information available to journalists and political scientists, thus making possible a reasonable appraisal of the program's over-all impact, and enabling management's concern for public reaction to serve as an effective check on excessive expenditures and on the selection of propaganda objectives.

If the several dangers latent in corporate political programs do in fact materialize, a second look at existing mechanisms to control their scope and administration seem in order. The control mechanisms examined in this

242. Instead, legislation will result from startling revelations of improper practices. Under these circumstances, statutes enacted are likely to be improperly drafted to achieve unanalyzed goals. This was one of the difficulties with the Corrupt Practices Acts passed as a result of a general public furor following in the wake of investigations into political contributions by corporations.

243. 48 Stat. 894 (1934); 15 U.S.C. \$ $78 \mathrm{~m}$ (1958).

244. 17 C.F.R. $\$ \S 240.13 a-1,210.5-03$ (b) (6) (1949). The statute and regulations apply solely to companies listed on a national securities exchange, thereby exempting a great many large, endocratic corporations from the disclosure requirements.

245. 17 C.F.R. $\$ \S 240.14 a-1$ to $240.14 a-9$ (1960 Supp.).

246. Cf. Abrams v. Allen, 297 N.Y. 52, 74 N.E.2d 305 (1947). 
Comment have proved, on analysis, to be inadequate to cope with the problems that may be posed. In part, this inadequacy stems from over-emphasis on the shareholder-who is probably least likely to be affected by corporate politicking-and, in part from the unsophisticated equation of corporate politics and corruption imbedded in the corrupt practices acts.

As suggested previously, dollar limitations on corporate political spending might protect the interests of shareholders and the public. But other controls would be necessary to protect the interests of employees.

Corporate political programs are not likely to intimidate unionized hourly rated workers, whose promotion, discharge, and job privileges are governed by collective bargaining agreements administered by unions. But the programs could seriously infringe upon the freedom of managerial employees who must depend upon the favor and acceptance of their superiors for advancement. Only one state has experimented with comprehensive legislation designed to control this. Section 3172 of the Mississippi Code imposes criminal sanctions upon any corporate officer or employee who uses actual or threatened discharge or a change in pay scale as a sanction to affect the vote of any employee. ${ }^{247}$ In addition, the statute prohibits an employee or officer from making any statement calculated to intimidate or coerce any employee in the exercise of his political rights. Finally, by forbidding an employer to request any employee to perform services for any candidate, the statute appears to protect employees from abuse of released-time programs. Wider enactment of legislation of this kind, and the addition of civil remedies, ${ }^{248}$ could assist managerial employees to retain their political independence in the face of extensive political efforts by managements.

At best, such statutes could strike at only the most flagrant abuses, since the subtle factors involved in assessing the competence of managerial employees would tend to obscure the presence of political discrimination. But, by articulating public concern for employee political independence and by occasional application of sanctions, the statute could serve as a reminder of the expected standard of behavior.

247. Miss. Code Ann. § 3172 (1957).

248. The Mississippi statute does not provide for civil remedies. An employee, therefore, could neither compel a company violating the statute to respond in damages nor secure appropriate equitable relief unless he had been hired for a term. Bell v. Faulkiner, 75 S.W.2d 612 (Mo. Ct. App. 1934). 